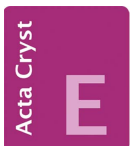

CRYSTALLOGRAPHIC COMMUNICATIONS

ISSN 2056-9890

Received 2 April 2019

Accepted 8 April 2019

Edited by W. T. A. Harrison, University of Aberdeen, Scotland

‡ Additional correspondence author, e-mail: mmjotani@rediffmail.com.

Keywords: crystal structure; 1,2-bis(phenyl)ethane; Hirshfeld surface analysis; interaction energies.

CCDC references: 1908484; 1908483

Supporting information: this article has supporting information at journals.iucr.org/e
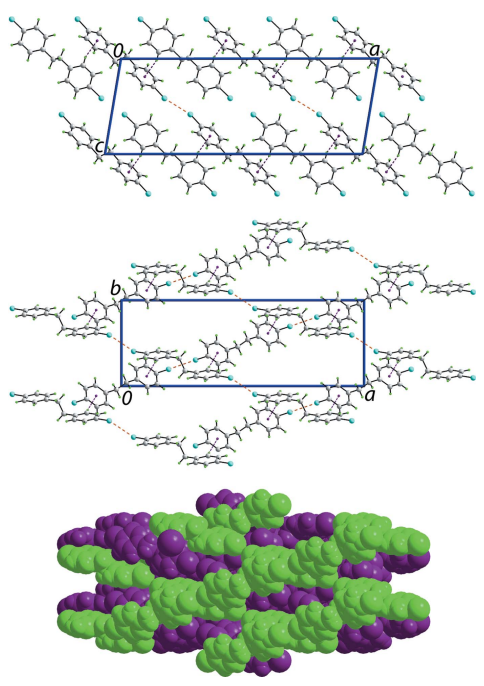

OPEN $\odot$ ACCESS

\section{1-Chloro-4-[2-(4-chlorophenyl)ethyl]benzene and its bromo analogue: crystal structure, Hirshfeld surface analysis and computational chemistry}

\author{
Mukesh M. Jotani, ${ }^{a} \neq$ See Mun Lee, ${ }^{\mathrm{b}}$ Kong Mun Lo ${ }^{\mathrm{b}}$ and Edward R. T. Tiekink ${ }^{\mathrm{b} *}$ \\ a'Department of Physics, Bhavan's Sheth R. A. College of Science, Ahmedabad, Gujarat 380001, India, and ${ }^{\mathbf{b}}$ Research \\ Centre for Crystalline Materials, School of Science and Technology, Sunway University, 47500 Bandar Sunway, Selangor \\ Darul Ehsan, Malaysia. *Correspondence e-mail: edwardt@sunway.edu.my
}

The crystal and molecular structures of $\mathrm{C}_{14} \mathrm{H}_{12} \mathrm{Cl}_{2}$, (I), and $\mathrm{C}_{14} \mathrm{H}_{12} \mathrm{Br}_{2}$, (II), are described. The asymmetric unit of (I) comprises two independent molecules, $A$ and $B$, each disposed about a centre of inversion. Each molecule approximates mirror symmetry [the $\mathrm{C}_{\mathrm{b}}-\mathrm{C}_{\mathrm{b}}-\mathrm{C}_{\mathrm{e}}-\mathrm{C}_{\mathrm{e}}$ torsion angles $=-83.46(19)$ and $95.17(17)^{\circ}$ for $A$, and -83.7 (2) and $94.75(19)^{\circ}$ for $B ; \mathrm{b}=$ benzene and $\mathrm{e}=$ ethylene]. By contrast, the molecule in (II) is twisted, as seen in the dihedral angle of $59.29(11)^{\circ}$ between the benzene rings $c f .0^{\circ}$ in (I). The molecular packing of (I) features benzene- $\mathrm{C}-\mathrm{H} \cdots \pi$ (benzene) and $\mathrm{Cl} \cdots \mathrm{Cl}$ contacts that lead to an open three-dimensional (3D) architecture that enables twofold 3D$3 \mathrm{D}$ interpenetration. The presence of benzene- $\mathrm{C}-\mathrm{H} \cdots \pi$ (benzene) and $\mathrm{Br} \cdots \mathrm{Br}$ contacts in the crystal of (II) consolidate the 3D architecture. The analysis of the calculated Hirshfeld surfaces confirm the influence of the benzene-C$\mathrm{H} \cdots \pi$ (benzene) and $X \cdots X$ contacts on the molecular packing and show that, to a first approximation, $\mathrm{H} \cdots \mathrm{H}, \mathrm{C} \cdots \mathrm{H} / \mathrm{H} \cdots \mathrm{C}$ and $\mathrm{C} \cdots X / X \cdots \mathrm{C}$ contacts dominate the packing, each contributing about $30 \%$ to the overall surface in each of (I) and (II). The analysis also clearly differentiates between the $A$ and $B$ molecules of (I).

\section{Chemical context}

The synthesis and physical characterization of the title compound, 1-chloro-4-[2-(4-chlorophenyl)ethyl]benzene, $\mathrm{C}_{14} \mathrm{H}_{12} \mathrm{Cl}_{2}$, (I), has been reported by several research groups over the years (Otsubo et al., 1980; Bestiuc et al., 1985; Parnes et al., 1989; Hu et al., 2011; Liu \& Li, 2007). In the same way, the bromo analogue of (I), 1-bromo-4-[2-(4-bromophenyl)ethyl]benzene, $\mathrm{C}_{14} \mathrm{H}_{12} \mathrm{Br}_{2}$, (II), has been described previously (Golden, 1961; Otsubo et al., 1980; Remizov et al., 2005; Liu \& Li, 2007). Despite this interest, crystallographic characterization is lacking. Recently, compounds (I) and (II) became available as minor side-products during the synthesis of the respective tri(4-halobenzyl)tin hydroxide from the reaction of tri(4-halobenzyl)tin halide and sodium hydroxide. Herein, the crystal and molecular structures of (I) and (II) are described. The structures are not isostructural and in order to gain further insight into the molecular packing, the structures were subjected to an analysis of their Hirshfeld surfaces along with some computational chemistry.

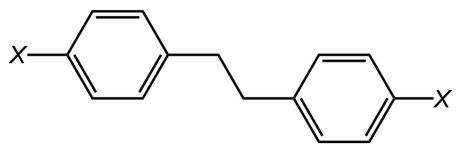

(I) $x=\mathrm{Cl}$; (II) $x=\mathrm{Br}$ 
(a)

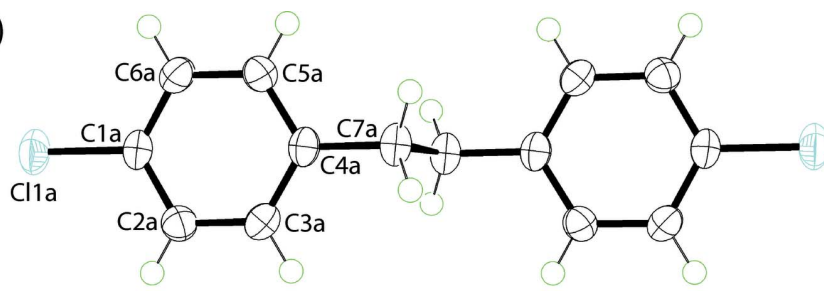

(b)

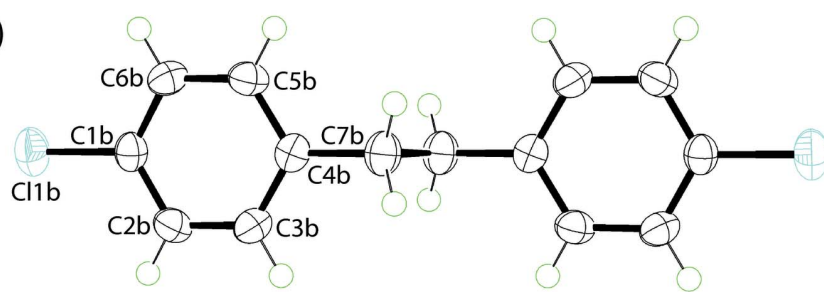

(c)

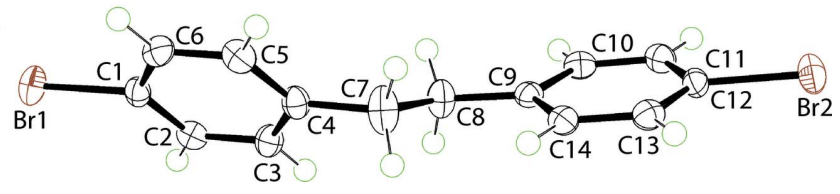

Figure 1

The molecular structures of $(a)$ the Cl1 $A$-containing molecule of (I), $(b)$ the Cl1 $B$-containing molecule of (I) and (c) the molecule of (II) showing the atom-labelling scheme and displacement ellipsoids at the $70 \%$ probability level. Unlabelled atoms in $(a)$ and $(b)$ are related by the symmetry operations $1-x, 1-y, 1-z$ and $\frac{1}{2}-x, \frac{3}{2}-y, 1-z$, respectively.

\section{Structural commentary}

The two independent molecules comprising the asymmetric unit of (I) are shown in Fig. 1(a) and (b); each is disposed about a centre of inversion. The molecules present very similar features and, from inversion symmetry, comprise parallel benzene rings. The $\mathrm{C} 3 A-\mathrm{C} 4 A-\mathrm{C} 7 A-\mathrm{C} 7 A^{\mathrm{i}}$ and $\mathrm{C} 5 A-$ $\mathrm{C} 4 A-\mathrm{C} 7 A-\mathrm{C} 7 A^{\mathrm{i}}$ torsion angles of $-83.46(19)$ and $95.17(17)^{\circ}$ highlight deviations from mirror symmetry in the molecule [symmetry operation: (i) $1-x, 1-y, 1-z$ ]. These values are equal within experimental error and are very close to the equivalent angles for the second independent molecule of -83.7 (2) and $94.75(19)^{\circ}$, respectively [symmetry operation: (ii) $\left.\frac{1}{2}-x, \frac{3}{2}-y, 1-z\right]$.

The molecule of (II) is shown in Fig. 1(c) and does not feature the molecular symmetry of (I). The difference in the conformation in (II), cf. (I), is seen immediately in the magnitude of the dihedral angle formed between the benzene rings of $59.29(11)^{\circ}$, indicating an inclined disposition. The

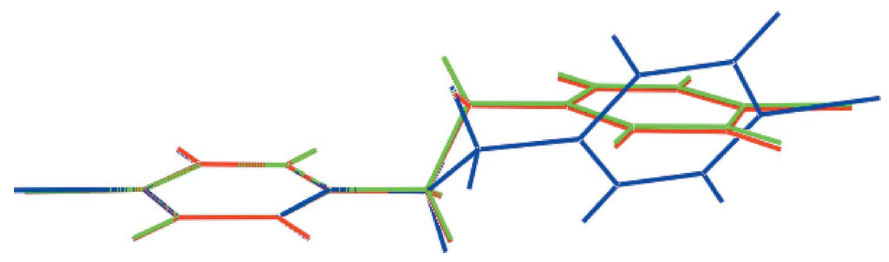

Figure 2

Overlap diagram of the (a) Cl1A-molecule in (I) (red image), (b) Cl1Bmolecule in (I) (green) and (c) the molecule in (II) (blue). Molecules have been overlapped so that the C1-benzene rings are coincident.
Table 1

Hydrogen-bond geometry $\left(\AA,^{\circ}\right)$ for (I).

$C g 1$ is the centroid of the $(\mathrm{C} 1 A-\mathrm{C} 6 A)$ ring.

\begin{tabular}{lllll}
\hline$D-\mathrm{H} \cdots A$ & $D-\mathrm{H}$ & $\mathrm{H} \cdots A$ & $D \cdots A$ & $D-\mathrm{H} \cdots A$ \\
\hline $\mathrm{C} 5 B-\mathrm{H} 5 B \cdots C g 1$ & 0.93 & 2.62 & $3.4866(15)$ & 155 \\
\hline
\end{tabular}

central torsion angle, i.e. $\mathrm{C} 4-\mathrm{C} 7-\mathrm{C} 8-\mathrm{C} 9$ of $172.1(2)^{\circ}$, deviates from the $180^{\circ}$ angles observed for the two independent molecules in (I). The twist in the molecule of (II) is reflected in the four torsion angles $\mathrm{C} 3-\mathrm{C} 4-\mathrm{C} 7-\mathrm{C} 8$ [46.6 (3) $\left.)^{\circ}\right], \mathrm{C} 5-\mathrm{C} 4-\mathrm{C} 7-\mathrm{C} 8\left[-134.8(2)^{\circ}\right], \mathrm{C} 7-\mathrm{C} 8-\mathrm{C} 9-$ $\mathrm{C} 14\left[16.4(3)^{\circ}\right]$ and $\mathrm{C} 7-\mathrm{C} 8-\mathrm{C} 9-\mathrm{C} 10\left[-163.7(2)^{\circ}\right]$.

The conformational differences between the molecules in (I) and (II) are highlighted in the overlay diagram shown in Fig. 2.

\section{Supramolecular features}

In the crystal of (I), the main point of contact between the independent molecules comprising the asymmetric unit are of the type benzene- $\mathrm{C}-\mathrm{H} \cdots \pi$ (benzene), Table 1 . The result is

(a)

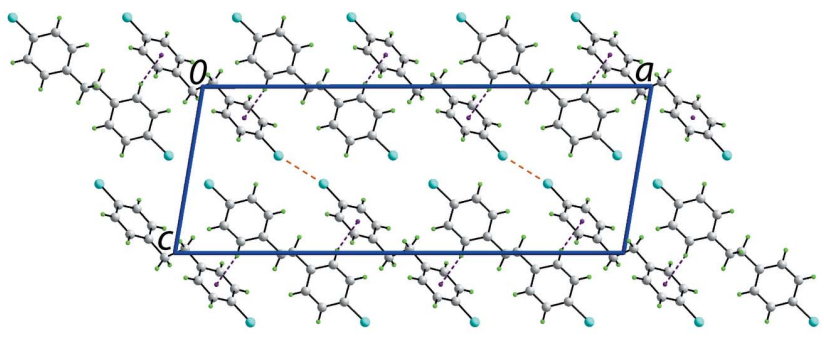

(b)

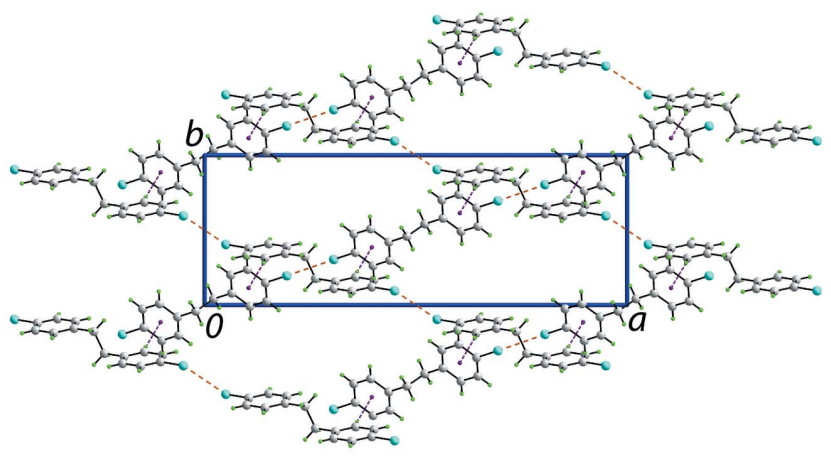

(c)

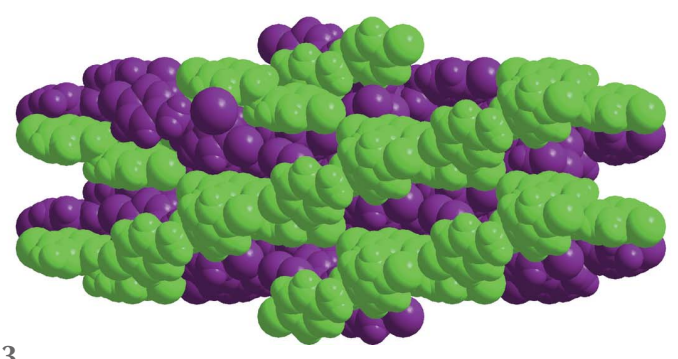

Figure 3

Molecular packing in (I): (a) a view of the supramolecular layer parallel to $[1 \overline{1} 0]$ sustained by $\mathrm{C}-\mathrm{H} \cdots \pi$ and $\mathrm{Cl} \cdots \mathrm{Cl}$ contacts shown as purple and orange dashed lines, respectively, $(b)$ a view of half of the unit-cell contents shown in projection down the $c$ axis and $(c)$ an image highlighting the twofold interpenetration in space-filling mode. 
Table 2

Hydrogen-bond geometry $\left(\AA{ }^{\circ}{ }^{\circ}\right)$ for (II).

$C g 1$ and $C g 2$ are the centroids of the $(\mathrm{C} 1-\mathrm{C} 6)$ and (C9-C14) rings, respectively.

\begin{tabular}{|c|c|c|c|c|}
\hline$D-\mathrm{H} \cdots A$ & $D-\mathrm{H}$ & $\mathrm{H} \cdots A$ & $D \cdots A$ & $D-\mathrm{H} \cdots A$ \\
\hline $\mathrm{C} 3-\mathrm{H} 3 \cdots C g 2^{\mathrm{i}}$ & 0.95 & 2.69 & $3.442(2)$ & 136 \\
\hline $\mathrm{C} 6-\mathrm{H} 6 \cdots C g 1^{\mathrm{ii}}$ & 0.95 & 2.91 & $3.704(2)$ & 141 \\
\hline $\mathrm{C} 13-\mathrm{H} 13 \cdots C g 2^{\mathrm{iii}}$ & 0.95 & 2.87 & $3.569(2)$ & 131 \\
\hline
\end{tabular}

the formation of a supramolecular chain along the $a$-axis direction. Chains are connected into a supramolecular layer via end-on $\mathrm{Cl} 1 A \cdots \mathrm{Cl} 1 A^{\mathrm{iii}}$ contacts [3.3184 (7) $\AA$ and $\mathrm{C} 1-$ $\mathrm{C} 11 A \cdots \mathrm{Cl} 1 A^{\mathrm{iii}}=164.61(5)^{\circ}$ for symmetry operation (iii) $\frac{1}{2}-x$, $\left.\frac{3}{2}-y,-z\right]$, Fig. 3(a). The topology of the layer is flat and connections between the layers that stack along [1피 are weaker end-on $\mathrm{Cl} 1 B \cdots \mathrm{Cl} 1 B^{\text {iv }}$ contacts $[3.4322(7) \AA$ and $\mathrm{C} 1 B-\mathrm{Cl} 1 B \cdots \mathrm{Cl} 1 B^{\mathrm{iv}}=155.19(5)^{\circ}$ for symmetry operation (iv) $1-x, 2-y, 2-z]$, which lead to a three-dimensional (3-D) architecture. As seen from Fig, 3(b), there are large voids defined by the aforementioned contacts which enables twofold, 3D-3D interpenetration, Fig. 3(c).

The 3-D architecture of (II) is supported by benzene-C$\mathrm{H} \cdots \pi$ (benzene) and $\mathrm{Br} \cdots \mathrm{Br}$ contacts. Globally, molecules assemble in the $a c$ plane and are connected to layers along [010] by benzene-C $-\mathrm{H} \cdots \pi$ (benzene) contacts, Table 2. Further, lateral interactions are $\operatorname{Br} 1 \cdots B r 2^{\mathrm{i}}$ [3.5242 (4) Å, $\mathrm{C} 1-\mathrm{Br} \cdots \mathrm{Br} 2^{\mathrm{i}}=144.67(7)^{\circ}$ and $\mathrm{C} 12^{\mathrm{i}}-\mathrm{Br} 2^{\mathrm{i}} \cdots \mathrm{Br} 1=$ $154.39(7)^{\circ}$ for symmetry operation (i) $1+x, y, 1+z$; Fig. 4].

\section{Hirshfeld surface analysis}

The Hirshfeld surface calculations for (I) and (II) were performed in accord with established procedures (Tan et al., 2019) with the aid of Crystal Explorer (Turner et al., 2017) to determine the influence of weak intermolecular interactions upon the molecular packing in the absence of conventional hydrogen bonds.

In the crystal of (I), with two independent molecules, labelled $A$ and $B$, disposed about a centre of inversion the
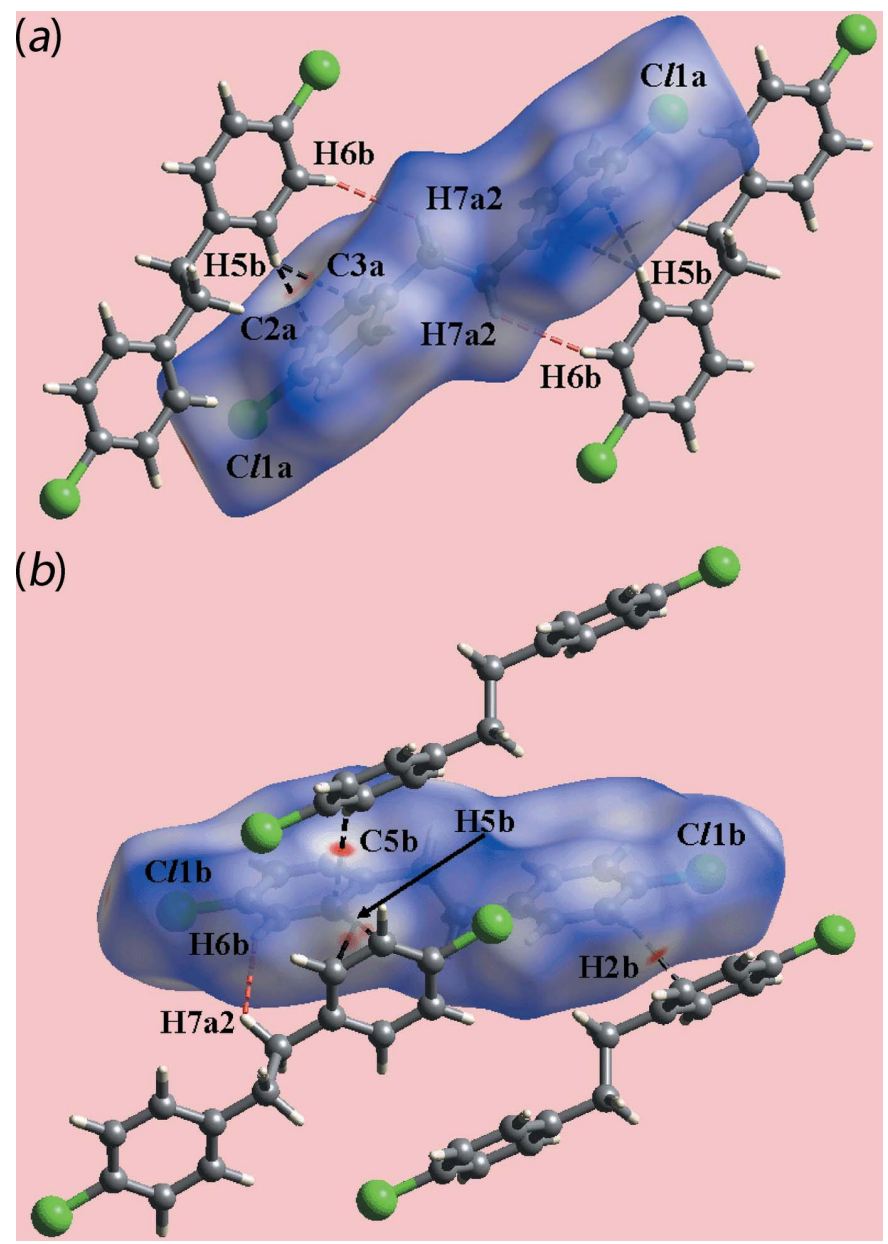

Figure 5

Views of the Hirshfeld surfaces for (I) mapped over $d_{\text {norm }}$ for $(a)$ molecule $A$ [in the range -0.103 to +1.259 arbitrary units] and $(b)$ molecule $B[-0.072$ to +1.234 arbitrary units $]$ highlighting the short interatomic $\mathrm{C} \cdots \mathrm{H} / \mathrm{H} \cdots \mathrm{C}$ and $\mathrm{H} \cdots \mathrm{H}$ contacts through black and red dashed lines, respectively.

presence of faint-red spots near the benzene-C $2 A, \mathrm{C} 3 A$ and $\mathrm{H} 5 B$ atoms in the images of Hirshfeld surfaces mapped over $d_{\text {norm }}$ in Fig. 5 represent $\mathrm{C}-\mathrm{H} \cdots \pi$ contacts, Tables 1 and 3. The diminutive red spot viewed near the benzene-C $5 B$ atom in Fig. $5(b)$ indicates the effect of a short interatomic C $5 B \cdots \mathrm{H} 2 B$

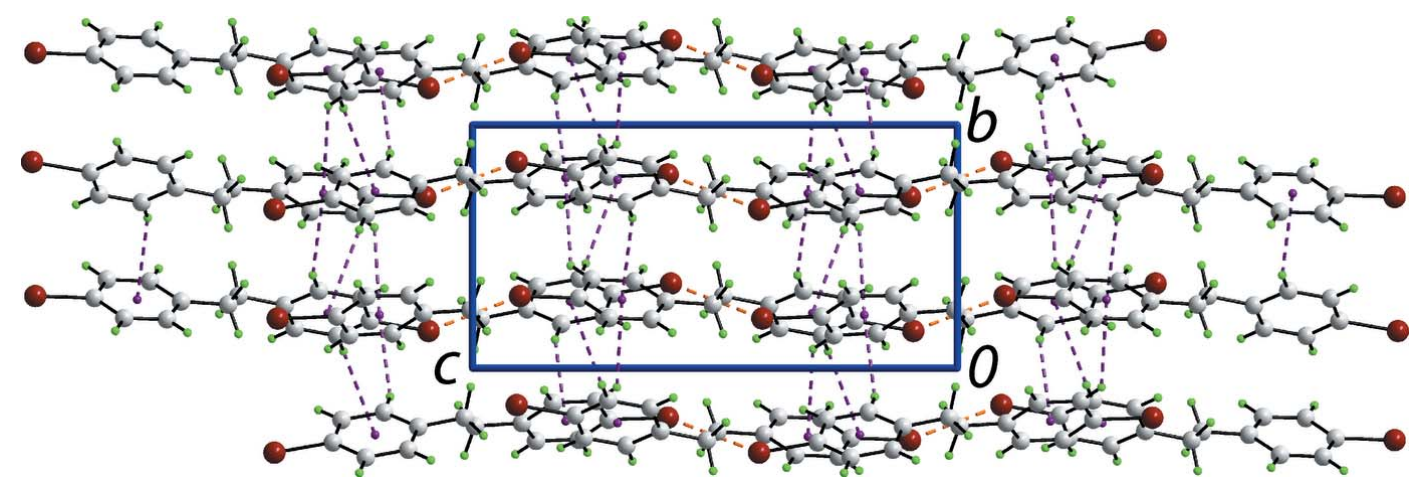

Figure 4

Molecular packing in (II): a view of the unit-cell contents shown in projection down the $a$ axis, highlighting $\mathrm{C}-\mathrm{H} \cdots \pi$ and $\mathrm{Br} \cdots \mathrm{Br}$ contacts as purple and orange dashed lines, respectively. 
Table 3

Summary of short interatomic contacts $(\AA)$ in $(\mathrm{I})^{a}$.

\begin{tabular}{lll}
\hline Contact & Distance & Symmetry operation \\
\hline (I) & & \\
$\mathrm{H} 6 B \cdots \mathrm{H} 72 A$ & 2.35 & $x, y, z$ \\
$\mathrm{H} 5 B \cdots \mathrm{C} 2 A$ & 2.75 & $x, y, z$ \\
$\mathrm{H} 5 B \cdots \mathrm{C} 3 A$ & 2.72 & $x, y, z$ \\
$\mathrm{H} 2 B \cdots \mathrm{C} 5 B$ & 2.67 & $x, 2-y, \frac{1}{2}+z$ \\
$\mathrm{C} 11 A \cdots \mathrm{Cl} 1 A$ & $3.3184(7)$ & $\frac{1}{2}-x, \frac{3}{2}-y,-z$ \\
$\mathrm{Cl} 1 B \cdots \mathrm{C} 1 B$ & $3.4322(7)$ & $1-x, 2-y, 2-z$ \\
$(\mathrm{II})$ & & \\
$\mathrm{H} 8 B \cdots \mathrm{H} 8 B$ & 2.21 & $-x, 2-y, 1-z$ \\
$\mathrm{H} 3 \cdots \mathrm{C} 13$ & 2.74 & $-x, 1-y, 1-z$ \\
$\mathrm{H} 3 \cdots \mathrm{C} 14$ & 2.72 & $1-x, \frac{1}{2}+y, \frac{3}{2}-z$ \\
$\mathrm{H} 6 \cdots \mathrm{C} 1$ & 2.82 & $1-x, \frac{1}{2}+y, \frac{3}{2}-z$ \\
$\mathrm{H} 6 \cdots \mathrm{C} 2$ & 2.62 & $-x, 2-y, 1-z$ \\
$\mathrm{H} 11 \cdots \mathrm{C} 6$ & 2.80 & $1+x, y, 1+z$ \\
$\mathrm{Br} 1 \cdots \mathrm{Br} 2$ & $3.5242(4)$ & \\
\hline
\end{tabular}

Notes: (a) The interatomic distances are calculated in Crystal Explorer (Turner et al., 2017) whereby the $X-\mathrm{H}$ bond lengths are adjusted to their neutron values.

contact, Table 3. Also, the presence of diminutive red spots near the terminal chlorine atoms of both independent molecules in Fig. 5 are due to the formation of short interatomic $\mathrm{Cl} \cdots \mathrm{Cl}$ contacts, Table 3 .
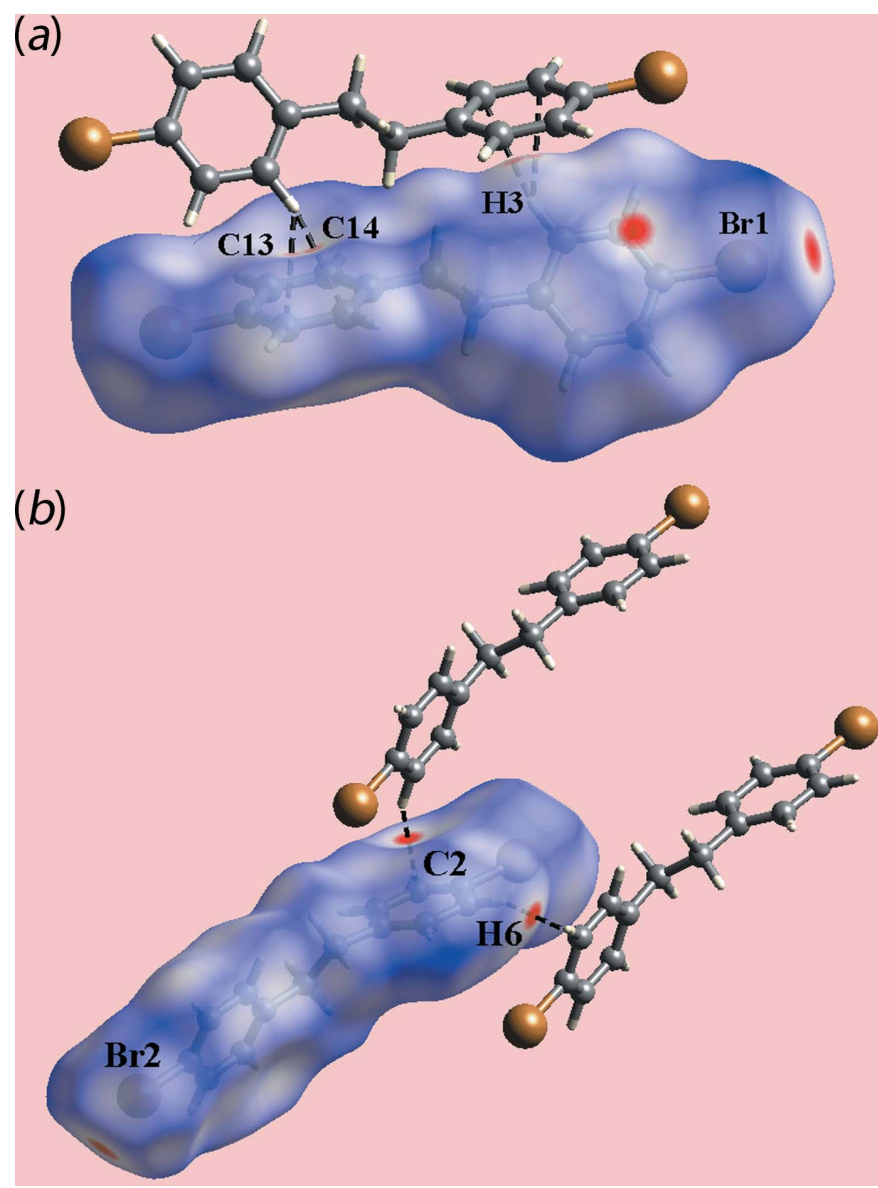

Figure 6

Views of the Hirshfeld surfaces for (II) mapped over $d_{\text {norm }}$ [in the range -0.104 to +1.172 arbitrary units] highlighting the short interatomic $\mathrm{C} \cdots \mathrm{H} / \mathrm{H} \cdots \mathrm{C}$ contacts through black dashed lines.
In the crystal of (II), the bright-red spots near the bromine atoms on the Hirshfeld surfaces mapped over $d_{\text {norm }}$ in Fig. 6 indicate interatomic $\mathrm{Br} \cdot \mathrm{Br}$ contacts, Table 3 , whereas those near the benzene-C2 and $\mathrm{H} 6$ atoms in Fig. $6(b)$ indicate short interatomic $\mathrm{C}-\mathrm{H} \cdots \pi$ interactions, Table 3 . The presence of faint-red spots near the benzene-C13, $\mathrm{C} 14$ and $\mathrm{H} 3$ atoms in Fig. 6(a) also reflect the presence of $\mathrm{C}-\mathrm{H} \cdots \pi$ contacts, Table 3.

From the views of Hirshfeld surfaces mapped over the calculated electrostatic potentials in Figs. 7(a) and $(b)$ for the independent molecules of (I) highlight the small deviations from putative mirror symmetry through the slight differences in the blue and red regions around the atoms of their surfaces corresponding, respectively, to positive and negative potentials. For (II), Fig.7(c), the donors and acceptors of the $\mathrm{C}-$ $\mathrm{H} \cdots \pi$ interactions are viewed as blue bumps and light-red concave regions. Further, the donors and acceptors of the $\mathrm{C}-$ $\mathrm{H} \cdots \pi$ contacts for each of (I) and (II) are also illustrated through black dotted lines on the Hirshfeld surfaces mapped with shape-index properties in Fig. 8.
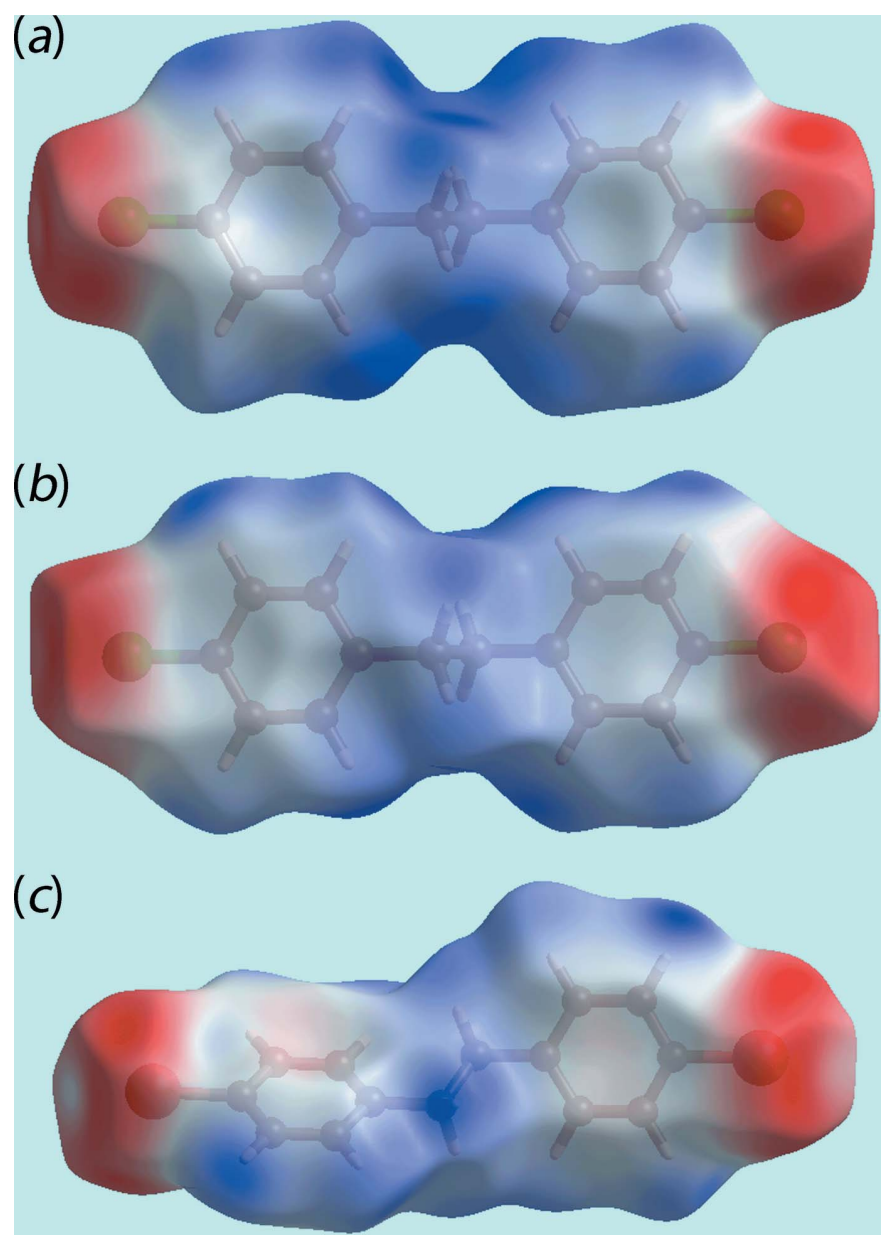

Figure 7

Views of the Hirshfeld surfaces mapped over the calculated electrostatic potential for $(a)(\mathrm{I})$, molecule $A$ [ -0.032 to +0.035 a.u.], $(b)(\mathrm{I})$, molecule $B$ in $[-0.033$ to +0.044 a.u.] range and (c) (II) $[-0.022$ to +0.039 a.u. $]$. The red and blue regions represent negative and positive electrostatic potentials, respectively. 
Table 4

Percentage contributions of interatomic contacts to the Hirshfeld surface for (I) and (II).

\begin{tabular}{lllll}
\hline Contact & Percentage contribution & & & \\
\hline & $(\mathrm{I})-$ molecule $A$ & (I) - molecule $B$ & $(\mathrm{I})$ & $(\mathrm{II})$ \\
$\mathrm{H} \cdots \mathrm{H}$ & 30.8 & 35.1 & 31.4 & 30.6 \\
$\mathrm{C} \cdots \mathrm{H} / \mathrm{H} \cdots \mathrm{C}$ & 32.5 & 27.0 & 28.4 & 32.7 \\
$X \cdots \mathrm{H} / \mathrm{H} \cdots X$ & 30.5 & 33.3 & 34.2 & 30.4 \\
$X \cdots X$ & 3.9 & 2.2 & 3.4 & 4.9 \\
$\mathrm{C} \cdots \mathrm{C}$ & 1.3 & 1.3 & 1.4 & 0.0 \\
$\mathrm{C} \cdots X / X \cdots \mathrm{C}$ & 1.1 & 1.1 & 1.2 & 1.4 \\
\hline
\end{tabular}

The overall two-dimensional fingerprint plot for the independent molecules $A$ and $B$ as well as entire (I) are shown in Fig. $9(a)$, and those delineated into $\mathrm{H} \cdots \mathrm{H}, \mathrm{C} \cdots \mathrm{H} / \mathrm{H} \cdots \mathrm{C}$, $\mathrm{Cl} \cdots \mathrm{H} / \mathrm{H} \cdots \mathrm{Cl}$ and $\mathrm{Cl} \cdots \mathrm{Cl}$ contacts are illustrated in Fig. 9(b)$(e)$, respectively. The quantitative summary of percentage contributions from the different interatomic contacts to the respective Hirshfeld surfaces of $A, B$ and (I) are presented in Table 4.

Some qualitative differences in the fingerprint plots are evident for molecules $A$ and $B$, confirming their distinct packing interactions. The complementary pair of forceps-like tips at $d_{\mathrm{e}}+d_{\mathrm{i}} \sim 2.3 \AA$ in the fingerprint plots delineated into $\mathrm{H} \cdot \cdots \mathrm{H}$ contacts for $A$ and $B$ in Fig. $9(b)$ represent the short interatomic $\mathrm{H} \cdots \mathrm{H}$ contact, Table 3 , which merge to form a pair of tips in the overall plot for (I). The fingerprint plots delineated into $\mathrm{C} \cdots \mathrm{H} / \mathrm{H} \cdots \mathrm{C}$ contacts for molecules $A$ and $B$ in Fig. $9(c)$ exhibit the clearest distinction between the interatomic contacts formed by the molecules through the asymmetric distribution of points. The complementary distribution of points in the acceptor and donor regions of the plots for $A$ and $B$, respectively, with the peaks at $d_{\mathrm{e}}+d_{\mathrm{i}} \sim 2.7 \AA$, are due to the formation of short interatomic $\mathrm{C} \cdots \mathrm{H} / \mathrm{H} \cdots \mathrm{C}$ contacts between the benzene-C $2 A, \mathrm{C} 3 A$ and $\mathrm{H} 5 B$ atoms, Table 3 . Similar short interatomic contacts between benzene-C5B and $\mathrm{H} 2 B$ atoms of $B$ results in forceps-like tips at $d_{\mathrm{e}}+d_{\mathrm{i}} \sim 2.7 \AA$ in the acceptor region of the plot whereas it is merged within the tip of previously mentioned contact in the donor region. However, the respective plot for an overall structure is symmetric owing to the merging of the asymmetric distribution of points. The significant and quite similar contributions from $\mathrm{Cl} \cdots \mathrm{H} / \mathrm{H} \cdots \mathrm{Cl}$ contacts to the Hirshfeld surfaces of $A, B$ and overall (I), Fig. $9(d)$, have very little influence on the molecular packing due to their interatomic distances being equal to or greater than the sum of their van der Waals radii.
(I), molecule-A

(a)

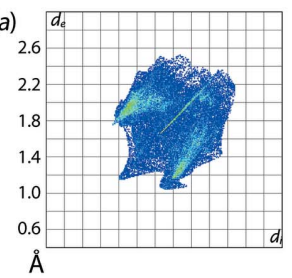

(b) 2.6

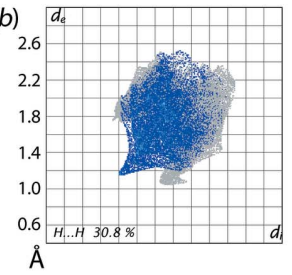

(c)

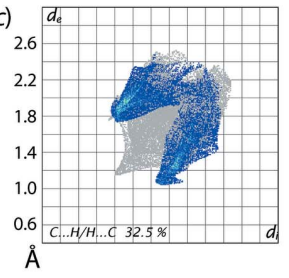

(d)
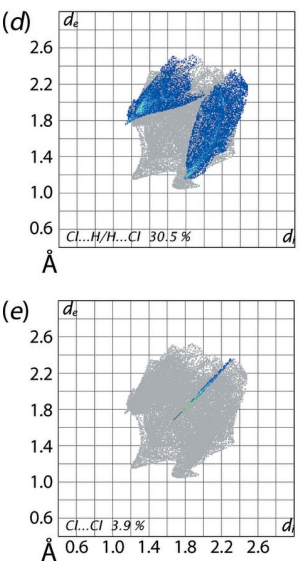

(I), molecule-B
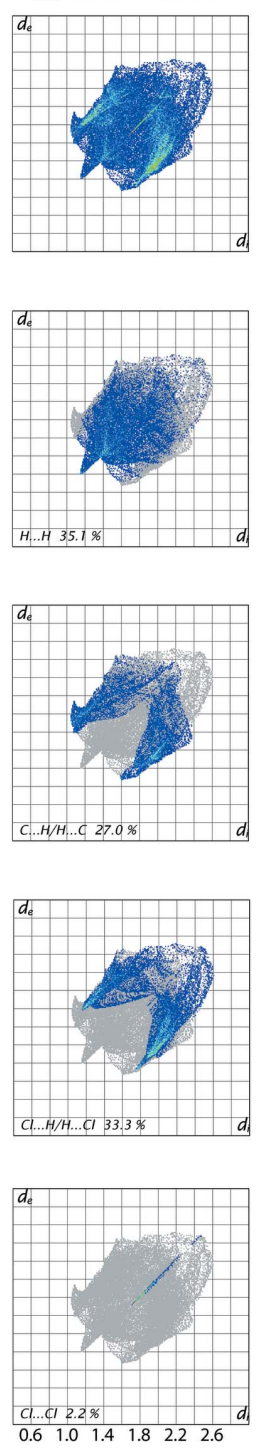

overall (I)
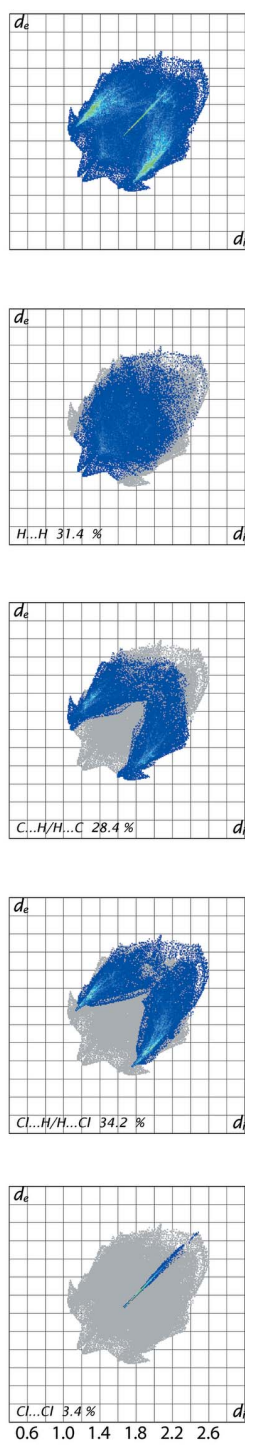

Figure 9

(a) The full two-dimensional fingerprint plot for molecule $A$ of (I), molecule $B$ of $(\mathrm{I})$, and overall $(\mathrm{I})$, and $(b)-(e)$ those delineated into $\mathrm{H} \cdots \mathrm{H}, \mathrm{C} \cdots \mathrm{H} / \mathrm{H} \cdots \mathrm{C}, \mathrm{Cl} \cdots \mathrm{H} / \mathrm{H} \cdots \mathrm{Cl}$ and $\mathrm{Cl} \cdots \mathrm{Cl}$ contacts.

The linear distribution of points beginning from $d_{\mathrm{e}}+d_{\mathrm{i}} \sim 3.3$ and $3.4 \AA$, Fig. $9(e)$, in the $\mathrm{Cl} \cdots \mathrm{Cl}$ delineated plots for $A$ and $B$, respectively, indicate the presence of $\mathrm{Cl} \cdots \mathrm{Cl}$ interactions. The small contribution from C...C contacts to the Hirshfeld surface of (I) has a negligible effect on the packing.

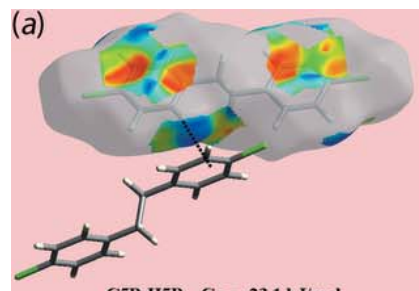

$\mathrm{C} 5 \mathrm{~B}-\mathrm{H} 5 \mathrm{~B} . . \mathrm{Cg}=-23.1 \mathrm{~kJ} / \mathrm{mol}$

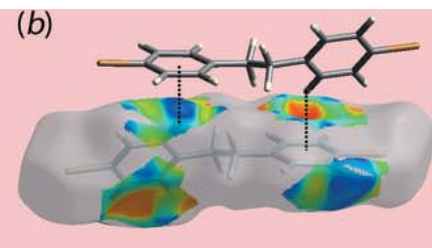

$\mathrm{C} 3-\mathrm{H} 3 \ldots \mathrm{Cg}(2)=-43.2 \mathrm{~kJ} / \mathrm{mol}$

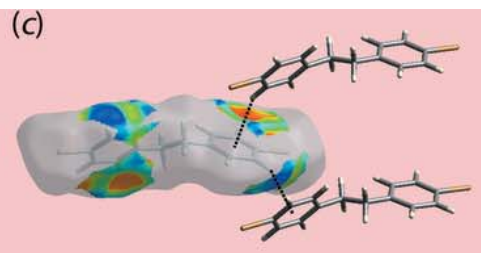

$\mathrm{C6}-\mathrm{H} 6 \ldots \mathrm{Cg}(1)=-16.7 \mathrm{~kJ} / \mathrm{mol}$

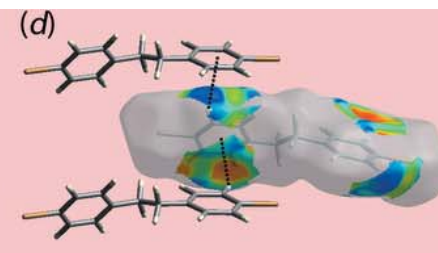

$\mathrm{C} 13-\mathrm{H} 13 \ldots \mathrm{Cg}(2)=-25.9 \mathrm{~kJ} / \mathrm{mol}$

Figure 8

Views of the Hirshfeld surfaces mapped with the shape index property for $(a)(\mathrm{I})$, molecule $B,(b)-(d)$ (II), highlighting intermolecular $\mathrm{C}-\mathrm{H} \cdots \pi$ interactions through black dotted lines. 


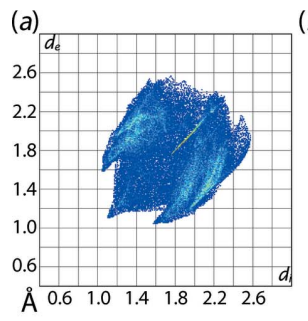

(b)

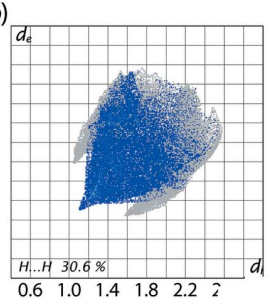

(c)
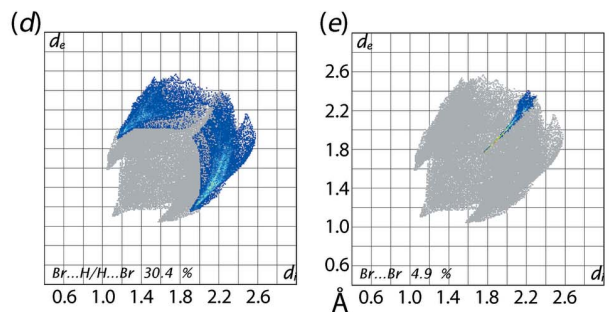

Figure 10

(a) The full two-dimensional fingerprint plot for (II), and $(b)-(e)$ those delineated into $\mathrm{H} \cdots \mathrm{H}, \mathrm{C} \cdots \mathrm{H} / \mathrm{H} \cdots \mathrm{C}, \mathrm{Br} \cdots \mathrm{Br}$ and $\mathrm{Br} \cdots \mathrm{H} / \mathrm{H} \cdots \mathrm{Br}$ contacts.

Comparable fingerprint plots for (II) are shown in Fig. 10 and percentage contributions are collected in Table 4. The short interatomic $\mathrm{H} \cdots \mathrm{H}$ contact between symmetry-related ethylene-H8B atoms is viewed as a single peak at $d_{\mathrm{e}}+d_{\mathrm{i}}$ $\sim 2.2 \AA$ in Fig. 10(b). In Fig. 10(c), delineated into C. .H/ $\mathrm{H} \cdot \mathrm{C}$ contacts, Table 3 , the forceps-like tips at $d_{\mathrm{e}}+d_{\mathrm{i}} \sim 2.6 \AA$ reflect the significant $\mathrm{C}-\mathrm{H} \cdots \pi$ contacts in the molecular packing. The contribution of $\mathrm{Br} \cdots \mathrm{H} / \mathrm{H} \cdots \mathrm{Br}$ contacts to the
Table 5

Summary of interaction energies $\left(\mathrm{kJ} \mathrm{mol}^{-1}\right)$ calculated for (I) and (II).

\begin{tabular}{llllll}
\hline Contact & $E_{\text {ele }}$ & $E_{\mathrm{pol}}$ & $E_{\text {dis }}$ & $E_{\text {rep }}$ & $E_{\text {tot }}$ \\
\hline
\end{tabular}

(I)

$\mathrm{Cl} 1 A \cdots \mathrm{Cl} 1 A$

$\mathrm{Cl} 1 B \ldots \mathrm{Cl} 1 B$

$\mathrm{C} 5-\mathrm{H} 5 \cdots C g(\mathrm{C} 1 A-\mathrm{C} 6 A)$

$\mathrm{C} 5 \cdots \mathrm{H} 2 B$

(II)

$\mathrm{Br} 1 \cdots \mathrm{Br} 2$

$\mathrm{C} 3-\mathrm{H} 3 \cdots \mathrm{Cg}(\mathrm{C} 9-\mathrm{C} 14)$

$\mathrm{C} 6-\mathrm{H} 6 \cdots C g(\mathrm{C} 1-\mathrm{C} 6)$

$\mathrm{C} 13-\mathrm{H} 13 \cdots \mathrm{Cg}(\mathrm{C} 9-\mathrm{C} 14)$

H11 …C6

$\mathrm{H} 8 B \cdots \mathrm{H} 8 B$

\begin{tabular}{lllll}
-0.9 & 0.0 & -3.3 & 7.6 & 0.9 \\
-0.9 & -0.1 & -3.4 & 5.8 & -0.4 \\
-8.5 & -1.5 & -33.5 & 26.1 & -23.1 \\
-3.7 & -0.8 & -18.2 & 12.9 & -12.3 \\
& & & & \\
-2.2 & -0.1 & -4.9 & 8.4 & 0.1 \\
-14.6 & -4.7 & -62.4 & 38.3 & -43.2 \\
-5.6 & -1.5 & -25.1 & 15.5 & -16.7 \\
-8.9 & -1.9 & -30.9 & 14.2 & -25.9 \\
-5.0 & -3.2 & -50.6 & 24.7 & -32.7 \\
-5.0 & -3.2 & -50.6 & 24.7 & -32.7 \\
\hline
\end{tabular}

Hirshfeld surface of (II), Fig. 10(d), have very little influence on the packing due to their interatomic distances being around the sum of their van der Waals radii. The short interatomic $\mathrm{Br} \cdots \mathrm{Br}$ contacts in (II) are viewed as a thin, linear distribution of points initiating from $d_{\mathrm{e}}+d_{\mathrm{i}} \sim 3.5 \AA$, Fig. 10(e). As for (I), the small contribution from C...C contacts to the Hirshfeld surface of (II) has a negligible effect in the crystal.

\section{Computational chemistry}

The pairwise interaction energies between the molecules in the crystals of (I) and (II) were calculated by summing up four energy components, being electrostatic $\left(E_{\text {ele }}\right)$, polarization

\section{molecule $A$ of (I)}

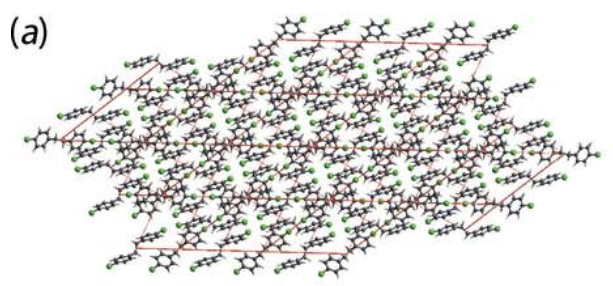

(b)
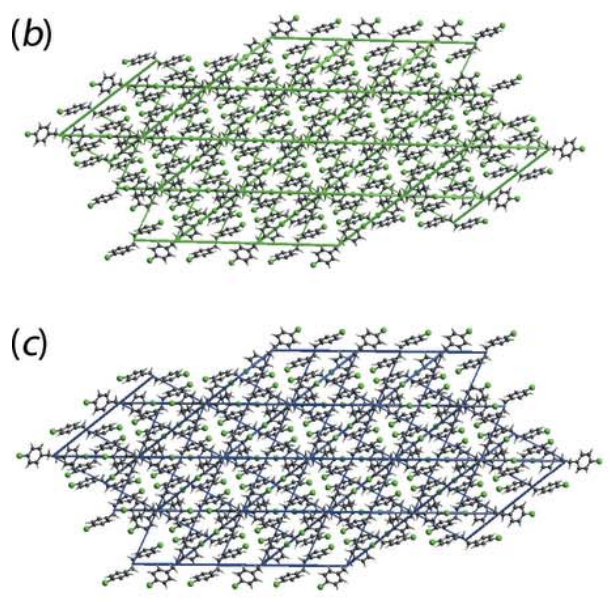

\section{molecule $B$ of (I)}
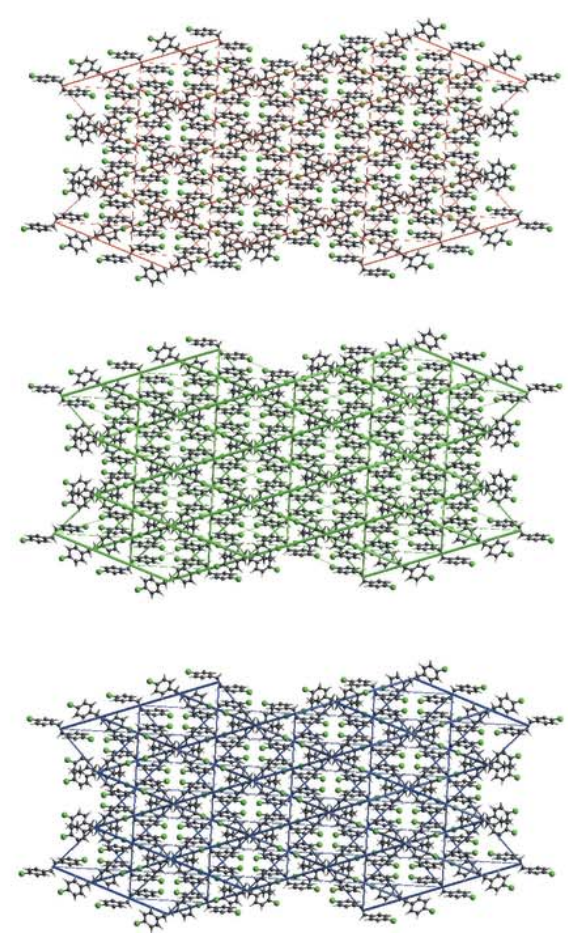

(II)
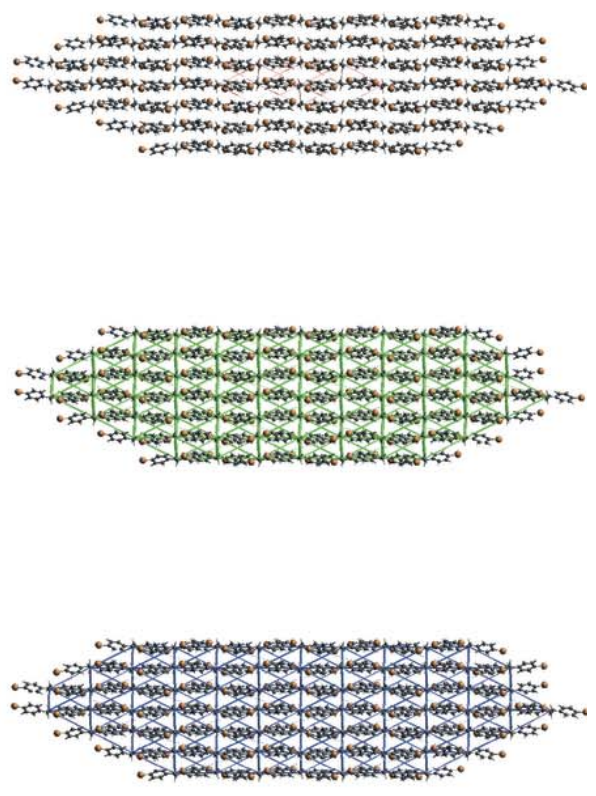

Figure 11

A comparison of the energy frameworks composed of (a) electrostatic potential force, $(b)$ dispersion force and $(c)$ total energy for cluster about a reference molecule of $A$ and $B$ of (I), and for (II). The energy frameworks were adjusted to the same scale factor of 80 with a cut-off value of $2 \mathrm{~kJ}^{\text {mol }}{ }^{-1}$ within $4 \times 4 \times 4$ unit cells. 
Table 6

Geometric data $\left(\AA,^{\circ}\right)$ for halo-substituted 1,2-bis(phenyl)ethane structures.

\begin{tabular}{|c|c|c|c|c|c|}
\hline Ring 1 & Ring 2 & Symmetry & $\mathrm{CH}_{2}-\mathrm{CH}_{2}$ & dihedral angle $\mathrm{C}_{6} / \mathrm{C}_{6}$ & Reference \\
\hline 2- $\mathrm{BrC}_{6} \mathrm{H}_{4}$ & $2-\mathrm{BrC}_{6} \mathrm{H}_{4}$ & $\overline{1}$ & $1.540(7)$ & 0 & Kahr et al. (1995) \\
\hline $\mathrm{C}_{6} \mathrm{~F}_{5}$ & $\mathrm{C}_{6} \mathrm{~F}_{5}$ & $\overline{1}$ & $1.542(3)$ & 0 & Krafczyk et al. (1997) \\
\hline $\mathrm{C}_{6} \mathrm{Br}_{5}$ & $\mathrm{C}_{6} \mathrm{Br}_{5}$ & $\overline{1}$ & $1.495(13)$ & 0 & Köppen et al. (2007) \\
\hline \multirow[t]{2}{*}{$4-\mathrm{ClC}_{6} \mathrm{H}_{4}{ }^{a}$} & $4-\mathrm{ClC}_{6} \mathrm{H}_{4}$ & $\overline{1}$ & $1.530(2)$ & 0 & This work \\
\hline & & $\overline{1}$ & $1.530(3)$ & 0 & \\
\hline $4-\mathrm{BrC}_{6} \mathrm{H}_{4}$ & $4-\mathrm{BrC}_{6} \mathrm{H}_{4}$ & - & $1.516(3)$ & $59.29(11)$ & This work \\
\hline
\end{tabular}

Notes: (a) Two independent molecules comprise the asymmetric unit.

$\left(E_{\text {pol }}\right)$, dispersion $\left(E_{\text {dis }}\right)$ and exchange-repulsion $\left(E_{\text {rep }}\right)$ (Turner et al., 2017). These energies were obtained by using the wave functions calculated at the B3LYP/6-31G(d,p) level theory for (I) and the HF/STO-3G level theory for (II). The individual energy components as well as total interaction energy relative to reference molecule within molecular clusters out to $3.8 \AA$. The nature and strength of the energies for the key identified intermolecular interactions are quantitatively summarized in Table 5. Dispersive components are dominant as conventional hydrogen bonding is not possible.

The significant contributions from the $\mathrm{C}-\mathrm{H} \cdots \pi$ interaction and short interatomic $\mathrm{C} \cdots \mathrm{H} / \mathrm{H} \cdots \mathrm{C}$ contacts in the crystal of (I) are evident from Table 5. Also notable, are the negligible energies associated with the $\mathrm{Cl} \cdots \mathrm{Cl}$ contacts due to the dominance of repulsive contributions. With respect to (II), it is evident from the comparison of the dispersive component as well as total energies for the different interactions that the strength of interactions in the crystal depend upon distance between the respective molecules. The short $\mathrm{Br} \cdots \mathrm{Br}$ contacts in (II) also have very small interaction energies.

The magnitudes of intermolecular energies are represented graphically in the energy frameworks of Fig. 11. Here, the supramolecular architecture of each crystal is viewed through the cylinders joining the centroids of molecular pairs. The red $\left(E_{\text {ele }}\right)$, green $\left(E_{\text {disp }}\right)$ and blue $\left(E_{\text {tot }}\right)$ colour scheme represent the specified energy components. The radii of the cylinders are proportional to the magnitude of interaction energies which are adjusted with a cut-off value of $2 \mathrm{~kJ} \mathrm{~mol}^{-1}$ within $4 \times 4 \times$ 4 unit cells. The energy frameworks constructed for the clusters about the independent molecules $A$ and $B$ of (I) as well as that for (II) also indicate the distinct mode of supramolecular association around the molecules in the molecular packing. The small effect of the electrostatic components and the significant influence of the dispersive components are clearly evident from the energy frameworks shown in Fig. 11.

\section{Database survey}

There are only four halo-substituted 1,2-bis(phenyl)ethylene derivatives in the literature. The key structural parameters for these are summarized in Table 6. Only one literature structure is not disposed about a centre of inversion, namely the nonsymmetric, mixed-halo structure (4- $\left.\mathrm{Br}, 2,6-\mathrm{F}_{2} \mathrm{C}_{6} \mathrm{H}_{2}\right)$ $\mathrm{CH}_{2} \mathrm{CH}_{2} \mathrm{C}_{6} \mathrm{H}_{4} \mathrm{Br}-4$ (Galán et al., 2016). Generally, the central
$\mathrm{C}_{\mathrm{e}}-\mathrm{C}_{\mathrm{e}}(\mathrm{e}=$ ethylene $)$ bonds are long in these compounds with the exception being the pentabromo derivative, $\mathrm{C}_{6} \mathrm{Br}_{5} \mathrm{CH}_{2} \mathrm{CH}_{2} \mathrm{C}_{6} \mathrm{Br}_{5}$ (Köppen et al., 2007).

\section{Synthesis and crystallization}

Tri(4-chlorobenzyl)tin chloride was prepared by direct synthesis using tin powder (Merck) and 4-chlorobenzyl chloride (Sigma-Aldrich) in water (Sisido et al., 1961). Tri(4chlorobenzyl)tin chloride $(5.3 \mathrm{~g}, 10 \mathrm{mmol})$ was dissolved in $95 \%$ ethanol $(150 \mathrm{ml})$ and to this was added dropwise $10 \%$ sodium hydroxide solution $(4 \mathrm{ml})$. The resulting solution was heated for $1 \mathrm{~h}$. After cooling, the white tri(4-chlorobenzyl)tin hydroxide was filtered off and the filtrate was evaporated slowly to obtain a colourless crystalline solid which was identified crystallographically as (I). Yield: $0.28 \mathrm{~g}(0.11 \%)$. The bromo analogue was similarly obtained as a side-product from the base hydrolysis of tri(4-bromobenzyl)tin bromide. Tri(4-bromobenzyltin) bromide was prepared from the reaction of tin powder (Sigma-Aldrich) and 4-bromobenzyl bromide (Merck) in water (Sisido et al., 1961). Tri(4-bromobenzyl)tin bromide $(7.0 \mathrm{~g}, 10 \mathrm{mmol})$ was dissolved in $95 \%$ ethanol $(150 \mathrm{ml})$ and to this was added $10 \%$ sodium hydroxide solution (4 ml). The resulting precipitation was heated for $1 \mathrm{~h}$. After cooling, the yellow tri(4-bromobenzyl)tin hydroxide was filtered off and the filtrate was evaporated slowly to obtain a yellow crystalline solid which was identified crystallographically as (II). Yield: $0.25 \mathrm{~g}(0.07 \%)$

\section{Refinement}

Crystal data, data collection and structure refinement details are summarized in Table 7. The carbon-bound $\mathrm{H}$ atoms were placed in calculated positions $(\mathrm{C}-\mathrm{H}=0.93-0.99 \AA)$ and were included in the refinement in the riding-model approximation, with $U_{\text {iso }}(\mathrm{H})$ set to $1.2 U_{\text {eq }}(\mathrm{C})$. In the refinement of (II), owing to poor agreement the (111) reflection was omitted from the final cycles of refinement.

\section{Acknowledgements}

Sunway University Sdn Bhd is thanked for support. 
Table 7

Experimental details.

(I)

Crystal data

Chemical formula

$M_{\mathrm{r}}$

Crystal system, space group

Temperature (K)

$a, b, c(\AA)$

$\beta\left({ }^{\circ}\right)$

$V\left(\AA^{3}\right)$

$Z$

Radiation type

$\mu\left(\mathrm{mm}^{-1}\right)$

Crystal size (mm)

Data collection

Diffractometer

Absorption correction

$T_{\min }, T_{\max }$

No. of measured, independent and

observed $[I>2 \sigma(I)]$ reflections

$R_{\text {int }}$

$(\sin \theta / \lambda)_{\max }\left(\AA^{-1}\right)$

Refinement

$R\left[F^{2}>2 \sigma\left(F^{2}\right)\right], w R\left(F^{2}\right), S$

No. of reflections

No. of parameters

$\mathrm{H}$-atom treatment

$\Delta \rho_{\max }, \Delta \rho_{\min }\left(\mathrm{e} \AA^{-3}\right)$

\author{
$\mathrm{C}_{14} \mathrm{H}_{12} \mathrm{Cl}_{2}$ \\ 251.14 \\ Monoclinic, $C 2 / c$ \\ 296 \\ 26.6755 (19), 9.3259 (7), 10.0405 (8) \\ 99.560 (4) \\ $2463.1(3)$ \\ 8 \\ Mo $K \alpha$ \\ 0.50 \\ $0.30 \times 0.20 \times 0.10$
}

Bruker SMART APEX CCD area detector

Multi-scan (SADABS; Sheldrick, 1996)

$0.623,0.746$

12061, 3090, 2627

0.026

0.669

$0.033,0.090,1.04$

3090

145

$\mathrm{H}$-atom parameters constrained

$0.31,-0.27$
(II)

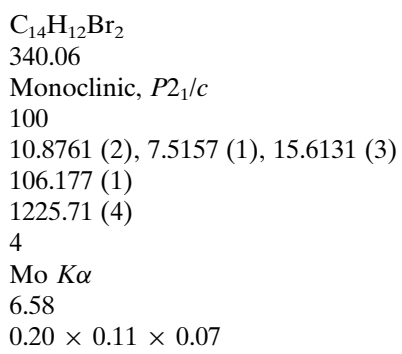

Bruker SMART APEX CCD area detector Multi-scan (SADABS; Sheldrick, 1996) $0.546,0.746$ $11908,3065,2520$

0.035

0.669

$0.026,0.058,1.03$

3065

145

$\mathrm{H}$-atom parameters constrained $0.45,-0.41$

Computer programs: APEX2 (Bruker, 2008), SAINT (Bruker, 2008), SHELXS97 (Sheldrick, 2008), SHELXL2018/3 (Sheldrick, 2015), ORTEP-3 for Windows (Farrugia, 2012), DIAMOND (Brandenburg, 2006), QMol (Gans \& Shalloway, 2001) and publCIF (Westrip, 2010).

\section{References}

Bestiuc, I., Buruiana, T., Idriceanu, S., Popescu, V. \& Caraculacu, A. (1985). Rev. Chim. 36, 621-623.

Brandenburg, K. (2006). DIAMOND. Crystal Impact GbR, Bonn, Germany.

Bruker (2008). APEX2 and SAINT. Bruker AXS Inc., Madison, Wisconsin, USA.

Farrugia, L. J. (2012). J. Appl. Cryst. 45, 849-854.

Galán, E., Perrin, M. L., Lutz, M., van der Zant, H. S. J., Grozema, F. C. \& Eelkema, R. (2016). Org. Biomol. Chem. 14, 2439-2443.

Gans, J. \& Shalloway, D. (2001). J. Mol. Graphics Modell. 19, 557-559. Golden, J. H. (1961). J. Chem. Soc. pp. 1604-1610.

Hu, Y.-L., Li, F., Gu, G.-L. \& Lu, M. (2011). Catal. Lett. 141, 467473.

Kahr, B., Mitchell, C. A., Chance, J. M., Clark, R. V., Gantzel, P., Baldridge, K. K. \& Siegel, J. S. (1995). J. Am. Chem. Soc. 117, 44794482.

Köppen, R., Emmerling, F. \& Becker, R. (2007). Acta Cryst. E63, o585-0586.
Krafczyk, R., Thönnessen, H., Jones, P. G. \& Schmutzler, R. (1997). J. Fluor. Chem. 83, 159-166.

Liu, J. \& Li, B. (2007). Synth. Commun. 37, 3273-3278.

Otsubo, T., Ogura, F., Yamaguchi, H., Higuchi, H. \& Misumi, S. (1980). Synth. Commun. 10, 595-601.

Parnes, Z. N., Romanova, V. S. \& Vol'pin, M. E. (1989). Zh. Org. Khim. 25, 1075-1079.

Remizov, A. B., Kamalova, D. I. \& Stolov, A. A. (2005). Russ. J. Phys. Chem. A, 79(Suppl. 1), 76-80.

Sheldrick, G. M. (1996). SADABS. University of Göttingen, Germany.

Sheldrick, G. M. (2008). Acta Cryst. A64, 112-122.

Sheldrick, G. M. (2015). Acta Cryst. C71, 3-8.

Sisido, K., Takeda, Y. \& Kinugawa, Z. (1961). J. Am. Chem. Soc. 83, 538-541.

Tan, S. L., Jotani, M. M. \& Tiekink, E. R. T. (2019). Acta Cryst. E75, 308-318.

Turner, M. J., Mckinnon, J. J., Wolff, S. K., Grimwood, D. J., Spackman, P. R., Jayatilaka, D. \& Spackman, M. A. (2017). Crystal Explorer 17. The University of Western Australia.

Westrip, S. P. (2010). J. Appl. Cryst. 43, 920-925. 


\section{supporting information}

Acta Cryst. (2019). E75, 624-631 [https://doi.org/10.1107/S2056989019004742]

\section{1-Chloro-4-[2-(4-chlorophenyl)ethyl]benzene and its bromo analogue: crystal structure, Hirshfeld surface analysis and computational chemistry}

\section{Mukesh M. Jotani, See Mun Lee, Kong Mun Lo and Edward R. T. Tiekink}

Computing details

For both structures, data collection: APEX2 (Bruker, 2008); cell refinement: SAINT (Bruker, 2008); data reduction: SAINT (Bruker, 2008); program(s) used to solve structure: SHELXS97 (Sheldrick, 2008); program(s) used to refine structure: SHELXL2018/3 (Sheldrick, 2015); molecular graphics: ORTEP-3 for Windows (Farrugia, 2012), DIAMOND (Brandenburg, 2006) and $Q M o l$ (Gans \& Shalloway, 2001); software used to prepare material for publication: publCIF (Westrip, 2010).

1-Chloro-4-[2-(4-chlorophenyl)ethyl]benzene (I)

Crystal data

$\mathrm{C}_{14} \mathrm{H}_{12} \mathrm{Cl}_{2}$

$M_{r}=251.14$

Monoclinic, $C 2 / c$

$a=26.6755(19) \AA$

$b=9.3259(7) \AA$

$c=10.0405(8) \AA$

$\beta=99.560(4)^{\circ}$

$V=2463.1(3) \AA^{3}$

$Z=8$

$F(000)=1040$

$D_{\mathrm{x}}=1.354 \mathrm{Mg} \mathrm{m}^{-3}$

Mo $K \alpha$ radiation, $\lambda=0.71073 \AA$

Cell parameters from 4470 reflections

$\theta=3.1-28.3^{\circ}$

$\mu=0.50 \mathrm{~mm}^{-1}$

$T=296 \mathrm{~K}$

Prism, colourless

$0.30 \times 0.20 \times 0.10 \mathrm{~mm}$

Data collection

Bruker model? CCD area detector diffractometer

Radiation source: fine-focus sealed tube

Graphite monochromator

$\varphi$ and $\omega$ scans

Absorption correction: multi-scan

(SADABS; Sheldrick, 1996)

$T_{\min }=0.623, T_{\max }=0.746$

12061 measured reflections

3090 independent reflections

2627 reflections with $I>2 \sigma(I)$

$R_{\text {int }}=0.026$

$\theta_{\text {max }}=28.4^{\circ}, \theta_{\min }=1.6^{\circ}$

$h=-35 \rightarrow 34$

$k=-11 \rightarrow 12$

$l=-13 \rightarrow 13$

Primary atom site location: structure-invariant direct methods

Hydrogen site location: inferred from neighbouring sites

$\mathrm{H}$-atom parameters constrained

$w=1 /\left[\sigma^{2}\left(F_{\mathrm{o}}^{2}\right)+(0.046 P)^{2}+1.4907 P\right]$

where $P=\left(F_{\mathrm{o}}^{2}+2 F_{\mathrm{c}}^{2}\right) / 3$

$(\Delta / \sigma)_{\max }=0.001$ 
$\Delta \rho_{\max }=0.31$ e $\AA^{-3}$

$\Delta \rho_{\min }=-0.27$ e $\AA^{-3}$

Special details

Geometry. All esds (except the esd in the dihedral angle between two 1.s. planes) are estimated using the full covariance matrix. The cell esds are taken into account individually in the estimation of esds in distances, angles and torsion angles; correlations between esds in cell parameters are only used when they are defined by crystal symmetry. An approximate (isotropic) treatment of cell esds is used for estimating esds involving l.s. planes.

Fractional atomic coordinates and isotropic or equivalent isotropic displacement parameters $\left(\hat{A}^{2}\right)$

\begin{tabular}{lllll}
\hline & $x$ & $y$ & $z$ & $U_{\text {iso }} * / U_{\text {eq }}$ \\
\hline C11A & $0.30558(2)$ & $0.69571(4)$ & $0.08421(3)$ & $0.02990(11)$ \\
C1A & $0.35616(5)$ & $0.64904(15)$ & $0.20984(13)$ & $0.0213(3)$ \\
C2A & $0.39856(5)$ & $0.73741(15)$ & $0.23346(13)$ & $0.0227(3)$ \\
H2A & 0.400392 & 0.819329 & 0.181667 & $0.027^{*}$ \\
C3A & $0.43825(5)$ & $0.70121(14)$ & $0.33594(13)$ & $0.0224(3)$ \\
H3A & 0.466935 & 0.759394 & 0.351988 & $0.027^{*}$ \\
C4A & $0.43591(5)$ & $0.57952(14)$ & $0.41510(13)$ & $0.0202(3)$ \\
C5A & $0.39306(5)$ & $0.49193(14)$ & $0.38683(13)$ & $0.0224(3)$ \\
H5A & 0.391223 & 0.409246 & 0.437578 & $0.027^{*}$ \\
C6A & $0.35314(5)$ & $0.52569(15)$ & $0.28454(13)$ & $0.0237(3)$ \\
H6A & 0.324808 & 0.466334 & 0.266505 & $0.028^{*}$ \\
C7A & $0.47884(5)$ & $0.54105(15)$ & $0.52636(13)$ & $0.0236(3)$ \\
H7A1 & 0.465754 & 0.482765 & 0.592893 & $0.028^{*}$ \\
H7A2 & 0.492801 & 0.628077 & 0.570743 & $0.028^{*}$ \\
C11B & $0.44971(2)$ & $0.90465(4)$ & $0.91449(4)$ & $0.03360(12)$ \\
C1B & $0.39561(5)$ & $0.87925(14)$ & $0.79317(14)$ & $0.0229(3)$ \\
C2B & $0.34836(6)$ & $0.90808(15)$ & $0.82606(14)$ & $0.0271(3)$ \\
H2B & 0.345284 & 0.938736 & 0.912478 & $0.033^{*}$ \\
C3B & $0.30571(5)$ & $0.89060(15)$ & $0.72836(15)$ & $0.0274(3)$ \\
H3B & 0.273843 & 0.910620 & 0.749858 & $0.033^{*}$ \\
C4B & $0.30929(5)$ & $0.84387(14)$ & $0.59888(13)$ & $0.0223(3)$ \\
C5B & $0.35742(5)$ & $0.81356(15)$ & $0.56992(14)$ & $0.0254(3)$ \\
H5B & 0.360595 & 0.780451 & 0.484341 & $0.031^{*}$ \\
C6B & $0.40064(5)$ & $0.83161(15)$ & $0.66564(14)$ & $0.0258(3)$ \\
H6B & 0.432599 & 0.811998 & 0.644554 & $0.031^{*}$ \\
C7B & $0.26239(5)$ & $0.82320(15)$ & $0.49401(15)$ & $0.0272(3)$ \\
H7B1 & 0.271471 & 0.832325 & 0.404772 & $0.033^{*}$ \\
H7B2 & 0.238029 & 0.898025 & 0.504017 & $0.033^{*}$ \\
& & & & \\
\end{tabular}

Atomic displacement parameters $\left(\AA^{2}\right)$

\begin{tabular}{lllllll}
\hline & $U^{11}$ & $U^{22}$ & $U^{33}$ & $U^{12}$ & $U^{13}$ & $U^{23}$ \\
\hline C11A & $0.02150(17)$ & $0.0400(2)$ & $0.02582(18)$ & $0.00466(13)$ & $-0.00301(12)$ & $0.00464(14)$ \\
C1A & $0.0173(6)$ & $0.0266(7)$ & $0.0191(6)$ & $0.0037(5)$ & $0.0005(5)$ & $-0.0009(5)$ \\
C2A & $0.0226(6)$ & $0.0237(6)$ & $0.0222(6)$ & $0.0005(5)$ & $0.0051(5)$ & $0.0011(5)$ \\
C3A & $0.0186(6)$ & $0.0257(6)$ & $0.0230(6)$ & $-0.0014(5)$ & $0.0041(5)$ & $-0.0029(5)$ \\
C4A & $0.0175(6)$ & $0.0246(6)$ & $0.0186(6)$ & $0.0046(5)$ & $0.0031(5)$ & $-0.0031(5)$ \\
C5A & $0.0230(6)$ & $0.0206(6)$ & $0.0236(6)$ & $0.0016(5)$ & $0.0035(5)$ & $0.0009(5)$
\end{tabular}




$\begin{array}{lllllll}\text { C6A } & 0.0199(6) & 0.0247(7) & 0.0258(7) & -0.0028(5) & 0.0017(5) & -0.0024(5) \\ \text { C7A } & 0.0199(6) & 0.0292(7) & 0.0207(6) & 0.0045(5) & 0.0003(5) & -0.0019(5) \\ \text { C11B } & 0.02872(19) & 0.0322(2) & 0.0356(2) & -0.00182(13) & -0.00707(15) & -0.00290(14) \\ \text { C1B } & 0.0223(6) & 0.0199(6) & 0.0251(6) & -0.0016(5) & 0.0001(5) & 0.0008(5) \\ \text { C2B } & 0.0296(7) & 0.0296(7) & 0.0233(7) & -0.0023(5) & 0.0076(6) & -0.0057(5) \\ \text { C3B } & 0.0214(6) & 0.0308(7) & 0.0313(7) & -0.0006(5) & 0.0084(5) & -0.0031(6) \\ \text { C4B } & 0.0211(6) & 0.0203(6) & 0.0250(6) & -0.0005(5) & 0.0024(5) & 0.0028(5) \\ \text { C5B } & 0.0279(7) & 0.0278(7) & 0.0215(6) & 0.0031(5) & 0.0067(5) & -0.0011(5) \\ \text { C6B } & 0.0216(6) & 0.0280(7) & 0.0286(7) & 0.0041(5) & 0.0069(5) & 0.0002(5) \\ \text { C7B } & 0.0251(7) & 0.0269(7) & 0.0276(7) & -0.0002(5) & -0.0011(6) & 0.0033(6) \\ & & & & & & \end{array}$

Geometric parameters $\left(A,{ }^{\circ}\right)$

\begin{tabular}{|c|c|c|c|}
\hline $\mathrm{C} 11 \mathrm{~A}-\mathrm{C} 1 \mathrm{~A}$ & $1.7424(13)$ & $\mathrm{C} 11 \mathrm{~B}-\mathrm{C} 1 \mathrm{~B}$ & $1.7432(13)$ \\
\hline $\mathrm{C} 1 \mathrm{~A}-\mathrm{C} 6 \mathrm{~A}$ & $1.3829(19)$ & $\mathrm{C} 1 \mathrm{~B}-\mathrm{C} 2 \mathrm{~B}$ & $1.381(2)$ \\
\hline $\mathrm{C} 1 \mathrm{~A}-\mathrm{C} 2 \mathrm{~A}$ & $1.3877(18)$ & $\mathrm{C} 1 \mathrm{~B}-\mathrm{C} 6 \mathrm{~B}$ & $1.383(2)$ \\
\hline $\mathrm{C} 2 \mathrm{~A}-\mathrm{C} 3 \mathrm{~A}$ & $1.3899(18)$ & $\mathrm{C} 2 \mathrm{~B}-\mathrm{C} 3 \mathrm{~B}$ & $1.383(2)$ \\
\hline $\mathrm{C} 2 \mathrm{~A}-\mathrm{H} 2 \mathrm{~A}$ & 0.9300 & $\mathrm{C} 2 \mathrm{~B}-\mathrm{H} 2 \mathrm{~B}$ & 0.9300 \\
\hline $\mathrm{C} 3 \mathrm{~A}-\mathrm{C} 4 \mathrm{~A}$ & $1.3928(19)$ & $\mathrm{C} 3 \mathrm{~B}-\mathrm{C} 4 \mathrm{~B}$ & $1.3895(19)$ \\
\hline $\mathrm{C} 3 \mathrm{~A}-\mathrm{H} 3 \mathrm{~A}$ & 0.9300 & $\mathrm{C} 3 \mathrm{~B}-\mathrm{H} 3 \mathrm{~B}$ & 0.9300 \\
\hline $\mathrm{C} 4 \mathrm{~A}-\mathrm{C} 5 \mathrm{~A}$ & $1.3952(18)$ & $\mathrm{C} 4 \mathrm{~B}-\mathrm{C} 5 \mathrm{~B}$ & $1.3917(18)$ \\
\hline $\mathrm{C} 4 \mathrm{~A}-\mathrm{C} 7 \mathrm{~A}$ & $1.5043(17)$ & $\mathrm{C} 4 \mathrm{~B}-\mathrm{C} 7 \mathrm{~B}$ & $1.5079(18)$ \\
\hline $\mathrm{C} 5 \mathrm{~A}-\mathrm{C} 6 \mathrm{~A}$ & $1.3873(18)$ & $\mathrm{C} 5 \mathrm{~B}-\mathrm{C} 6 \mathrm{~B}$ & $1.3832(19)$ \\
\hline $\mathrm{C} 5 \mathrm{~A}-\mathrm{H} 5 \mathrm{~A}$ & 0.9300 & $\mathrm{C} 5 \mathrm{~B}-\mathrm{H} 5 \mathrm{~B}$ & 0.9300 \\
\hline C6A-H6A & 0.9300 & $\mathrm{C} 6 \mathrm{~B}-\mathrm{H} 6 \mathrm{~B}$ & 0.9300 \\
\hline $\mathrm{C} 7 \mathrm{~A}-\mathrm{C} \mathrm{A}^{\mathrm{i}}$ & $1.530(2)$ & $\mathrm{C} 7 \mathrm{~B}-\mathrm{C} 7 \mathrm{~B}^{\mathrm{ii}}$ & $1.530(3)$ \\
\hline C7A-H7A1 & 0.9700 & $\mathrm{C} 7 \mathrm{~B}-\mathrm{H} 7 \mathrm{~B} 1$ & 0.9700 \\
\hline $\mathrm{C} 7 \mathrm{~A}-\mathrm{H} 7 \mathrm{~A} 2$ & 0.9700 & $\mathrm{C} 7 \mathrm{~B}-\mathrm{H} 7 \mathrm{~B} 2$ & 0.9700 \\
\hline $\mathrm{C} 6 \mathrm{~A}-\mathrm{C} 1 \mathrm{~A}-\mathrm{C} 2 \mathrm{~A}$ & $121.37(12)$ & $\mathrm{C} 2 \mathrm{~B}-\mathrm{C} 1 \mathrm{~B}-\mathrm{C} 6 \mathrm{~B}$ & $121.11(12)$ \\
\hline $\mathrm{C} 6 \mathrm{~A}-\mathrm{C} 1 \mathrm{~A}-\mathrm{C} 11 \mathrm{~A}$ & $119.51(10)$ & $\mathrm{C} 2 \mathrm{~B}-\mathrm{C} 1 \mathrm{~B}-\mathrm{C} 11 \mathrm{~B}$ & $119.26(11)$ \\
\hline $\mathrm{C} 2 \mathrm{~A}-\mathrm{C} 1 \mathrm{~A}-\mathrm{C} 11 \mathrm{~A}$ & $119.12(10)$ & $\mathrm{C} 6 \mathrm{~B}-\mathrm{C} 1 \mathrm{~B}-\mathrm{C} 11 \mathrm{~B}$ & $119.63(10)$ \\
\hline $\mathrm{C} 1 \mathrm{~A}-\mathrm{C} 2 \mathrm{~A}-\mathrm{C} 3 \mathrm{~A}$ & $118.77(12)$ & $\mathrm{C} 3 \mathrm{~B}-\mathrm{C} 2 \mathrm{~B}-\mathrm{C} 1 \mathrm{~B}$ & $118.90(13)$ \\
\hline $\mathrm{C} 1 \mathrm{~A}-\mathrm{C} 2 \mathrm{~A}-\mathrm{H} 2 \mathrm{~A}$ & 120.6 & $\mathrm{C} 3 \mathrm{~B}-\mathrm{C} 2 \mathrm{~B}-\mathrm{H} 2 \mathrm{~B}$ & 120.6 \\
\hline $\mathrm{C} 3 \mathrm{~A}-\mathrm{C} 2 \mathrm{~A}-\mathrm{H} 2 \mathrm{~A}$ & 120.6 & $\mathrm{C} 1 \mathrm{~B}-\mathrm{C} 2 \mathrm{~B}-\mathrm{H} 2 \mathrm{~B}$ & 120.6 \\
\hline $\mathrm{C} 2 \mathrm{~A}-\mathrm{C} 3 \mathrm{~A}-\mathrm{C} 4 \mathrm{~A}$ & $121.30(12)$ & $\mathrm{C} 2 \mathrm{~B}-\mathrm{C} 3 \mathrm{~B}-\mathrm{C} 4 \mathrm{~B}$ & $121.62(13)$ \\
\hline $\mathrm{C} 2 \mathrm{~A}-\mathrm{C} 3 \mathrm{~A}-\mathrm{H} 3 \mathrm{~A}$ & 119.4 & $\mathrm{C} 2 \mathrm{~B}-\mathrm{C} 3 \mathrm{~B}-\mathrm{H} 3 \mathrm{~B}$ & 119.2 \\
\hline $\mathrm{C} 4 \mathrm{~A}-\mathrm{C} 3 \mathrm{~A}-\mathrm{H} 3 \mathrm{~A}$ & 119.4 & $\mathrm{C} 4 \mathrm{~B}-\mathrm{C} 3 \mathrm{~B}-\mathrm{H} 3 \mathrm{~B}$ & 119.2 \\
\hline $\mathrm{C} 3 \mathrm{~A}-\mathrm{C} 4 \mathrm{~A}-\mathrm{C} 5 \mathrm{~A}$ & $118.28(12)$ & $\mathrm{C} 3 \mathrm{~B}-\mathrm{C} 4 \mathrm{~B}-\mathrm{C} 5 \mathrm{~B}$ & $117.94(12)$ \\
\hline $\mathrm{C} 3 \mathrm{~A}-\mathrm{C} 4 \mathrm{~A}-\mathrm{C} 7 \mathrm{~A}$ & $121.15(12)$ & $\mathrm{C} 3 \mathrm{~B}-\mathrm{C} 4 \mathrm{~B}-\mathrm{C} 7 \mathrm{~B}$ & $121.02(12)$ \\
\hline $\mathrm{C} 5 \mathrm{~A}-\mathrm{C} 4 \mathrm{~A}-\mathrm{C} 7 \mathrm{~A}$ & $120.55(12)$ & $\mathrm{C} 5 \mathrm{~B}-\mathrm{C} 4 \mathrm{~B}-\mathrm{C} 7 \mathrm{~B}$ & $121.03(12)$ \\
\hline $\mathrm{C} 6 \mathrm{~A}-\mathrm{C} 5 \mathrm{~A}-\mathrm{C} 4 \mathrm{~A}$ & $121.33(12)$ & $\mathrm{C} 6 \mathrm{~B}-\mathrm{C} 5 \mathrm{~B}-\mathrm{C} 4 \mathrm{~B}$ & $121.43(13)$ \\
\hline $\mathrm{C} 6 \mathrm{~A}-\mathrm{C} 5 \mathrm{~A}-\mathrm{H} 5 \mathrm{~A}$ & 119.3 & $\mathrm{C} 6 \mathrm{~B}-\mathrm{C} 5 \mathrm{~B}-\mathrm{H} 5 \mathrm{~B}$ & 119.3 \\
\hline $\mathrm{C} 4 \mathrm{~A}-\mathrm{C} 5 \mathrm{~A}-\mathrm{H} 5 \mathrm{~A}$ & 119.3 & $\mathrm{C} 4 \mathrm{~B}-\mathrm{C} 5 \mathrm{~B}-\mathrm{H} 5 \mathrm{~B}$ & 119.3 \\
\hline $\mathrm{C} 5 \mathrm{~A}-\mathrm{C} 6 \mathrm{~A}-\mathrm{C} 1 \mathrm{~A}$ & $118.92(12)$ & $\mathrm{C} 5 \mathrm{~B}-\mathrm{C} 6 \mathrm{~B}-\mathrm{C} 1 \mathrm{~B}$ & $118.99(12)$ \\
\hline $\mathrm{C} 5 \mathrm{~A}-\mathrm{C} 6 \mathrm{~A}-\mathrm{H} 6 \mathrm{~A}$ & 120.5 & $\mathrm{C} 5 \mathrm{~B}-\mathrm{C} 6 \mathrm{~B}-\mathrm{H} 6 \mathrm{~B}$ & 120.5 \\
\hline $\mathrm{C} 1 \mathrm{~A}-\mathrm{C} 6 \mathrm{~A}-\mathrm{H} 6 \mathrm{~A}$ & 120.5 & $\mathrm{C} 1 \mathrm{~B}-\mathrm{C} 6 \mathrm{~B}-\mathrm{H} 6 \mathrm{~B}$ & 120.5 \\
\hline $\mathrm{C} 4 \mathrm{~A}-\mathrm{C} 7 \mathrm{~A}-\mathrm{C} 7 \mathrm{~A}^{\mathrm{i}}$ & $112.14(13)$ & $\mathrm{C} 4 \mathrm{~B}-\mathrm{C} 7 \mathrm{~B}-\mathrm{C} 7 \mathrm{~B}^{\mathrm{ii}}$ & $112.23(14)$ \\
\hline
\end{tabular}




$\begin{array}{ll}\text { C4A-C7A-H7A1 } & 109.2 \\ \text { C7A-C7A-H7A1 } & 109.2 \\ \text { C4A-C7A-H7A2 } & 109.2 \\ \text { C7A-C7A-H7A2 } & 109.2 \\ \text { H7A1-C7A-H7A2 } & 107.9 \\ & \\ \text { C6A-C1A-C2A-C3A } & -0.98(19) \\ \text { C11A-C1A-C2A-C3A } & 178.52(10) \\ \text { C1A-C2A-C3A-C4A } & -0.5(2) \\ \text { C2A-C3A-C4A-C5A } & 1.63(19) \\ \text { C2A-C3A-C4A-C7A } & -179.71(12) \\ \text { C3A-C4A-C5A-C6A } & -1.28(19) \\ \text { C7A-C4A-C5A-C6A } & -179.95(12) \\ \text { C4A-C5A-C6A-C1A } & -0.2(2) \\ \text { C2A-C1A-C6A-C5A } & 1.3(2) \\ \text { C11A-C1A-C6A-C5A } & -178.18(10) \\ \text { C3A-C4A-C7A-C7A } & -83.46(19) \\ \text { C5A-C4A-C7A-C7A } & 95.17(17) \\ \end{array}$

$\begin{array}{ll}\text { C4B-C7B-H7B1 } & 109.2 \\ \text { C7B }{ }^{\mathrm{ii}}-\mathrm{C} 7 \mathrm{~B}-\mathrm{H} 7 \mathrm{~B} 1 & 109.2 \\ \mathrm{C} 4 \mathrm{~B}-\mathrm{C} 7 \mathrm{~B}-\mathrm{H} 7 \mathrm{~B} 2 & 109.2 \\ \mathrm{C} 7 \mathrm{~B}^{\mathrm{ii}}-\mathrm{C} 7 \mathrm{~B}-\mathrm{H} 7 \mathrm{~B} 2 & 109.2 \\ \mathrm{H} 7 \mathrm{~B} 1-\mathrm{C} 7 \mathrm{~B}-\mathrm{H} 7 \mathrm{~B} 2 & 107.9 \\ & \\ \mathrm{C} 6 \mathrm{~B}-\mathrm{C} 1 \mathrm{~B}-\mathrm{C} 2 \mathrm{~B}-\mathrm{C} 3 \mathrm{~B} & -1.0(2) \\ \mathrm{C} 11 \mathrm{~B}-\mathrm{C} 1 \mathrm{~B}-\mathrm{C} 2 \mathrm{~B}-\mathrm{C} 3 \mathrm{~B} & 178.62(11) \\ \mathrm{C} 1 \mathrm{~B}-\mathrm{C} 2 \mathrm{~B}-\mathrm{C} 3 \mathrm{~B}-\mathrm{C} 4 \mathrm{~B} & 0.5(2) \\ \mathrm{C} 2 \mathrm{~B}-\mathrm{C} 3 \mathrm{~B}-\mathrm{C} 4 \mathrm{~B}-\mathrm{C} 5 \mathrm{~B} & 0.5(2) \\ \mathrm{C} 2 \mathrm{~B}-\mathrm{C} 3 \mathrm{~B}-\mathrm{C} 4 \mathrm{~B}-\mathrm{C} 7 \mathrm{~B} & 179.08(13) \\ \mathrm{C} 3 \mathrm{~B}-\mathrm{C} 4 \mathrm{~B}-\mathrm{C} 5 \mathrm{~B}-\mathrm{C} 6 \mathrm{~B} & -1.2(2) \\ \mathrm{C} 7 \mathrm{~B}-\mathrm{C} 4 \mathrm{~B}-\mathrm{C} 5 \mathrm{~B}-\mathrm{C} 6 \mathrm{~B} & -179.72(13) \\ \mathrm{C} 4 \mathrm{~B}-\mathrm{C} 5 \mathrm{~B}-\mathrm{C} 6 \mathrm{~B}-\mathrm{C} 1 \mathrm{~B} & 0.8(2) \\ \mathrm{C} 2 \mathrm{~B}-\mathrm{C} 1 \mathrm{~B}-\mathrm{C} 6 \mathrm{~B}-\mathrm{C} 5 \mathrm{~B} & 0.3(2) \\ \mathrm{C} 11 \mathrm{~B}-\mathrm{C} 1 \mathrm{~B}-\mathrm{C} 6 \mathrm{~B}-\mathrm{C} 5 \mathrm{~B} & -179.24(11) \\ \mathrm{C} 3 \mathrm{~B}-\mathrm{C} 4 \mathrm{~B}-\mathrm{C} 7 \mathrm{~B}-\mathrm{C} 7 \mathrm{~B}^{\mathrm{ii}} & -83.7(2) \\ \mathrm{C} 5 \mathrm{~B}-\mathrm{C} 4 \mathrm{~B}-\mathrm{C} 7 \mathrm{~B}-\mathrm{C} 7 \mathrm{~B}^{\mathrm{ii}} & 94.75(19)\end{array}$

Symmetry codes: (i) $-x+1,-y+1,-z+1$; (ii) $-x+1 / 2,-y+3 / 2,-z+1$.

Hydrogen-bond geometry $\left(\AA,{ }^{\circ}\right)$

$\mathrm{Cg} 1$ is the centroid of the $(\mathrm{C} 1 A-\mathrm{C} 6 A)$ ring.

\begin{tabular}{lllll}
\hline$D-\mathrm{H} \cdots A$ & $D-\mathrm{H}$ & $\mathrm{H} \cdots A$ & $D \cdots A$ & $D-\mathrm{H} \cdots A$ \\
\hline $\mathrm{C} 5 B-\mathrm{H} 5 B \cdots C g 1$ & 0.93 & 2.62 & $3.4866(15)$ & 155 \\
\hline
\end{tabular}

1-Bromo-4-[2-(4-chlorophenyl)ethyl]benzene (II)

\section{Crystal data}

$\mathrm{C}_{14} \mathrm{H}_{12} \mathrm{Br}_{2}$

$M_{r}=340.06$

Monoclinic, $P 2_{1} / \mathrm{c}$

$a=10.8761(2) \AA$

$b=7.5157(1) \AA$

$c=15.6131(3) \AA$

$\beta=106.177(1)^{\circ}$

$V=1225.71(4) \AA^{3}$

$Z=4$

\section{Data collection}

Bruker model? CCD area detector diffractometer

Radiation source: fine-focus sealed tube Graphite monochromator $\varphi$ and $\omega$ scans

Absorption correction: multi-scan

(SADABS; Sheldrick, 1996)

$T_{\min }=0.546, T_{\max }=0.746$
$F(000)=664$

$D_{\mathrm{x}}=1.843 \mathrm{Mg} \mathrm{m}^{-3}$

Mo $K \alpha$ radiation, $\lambda=0.71073 \AA$

Cell parameters from 3449 reflections

$\theta=2.9-28.3^{\circ}$

$\mu=6.58 \mathrm{~mm}^{-1}$

$T=100 \mathrm{~K}$

Prism, colourless

$0.20 \times 0.11 \times 0.07 \mathrm{~mm}$

11908 measured reflections 3065 independent reflections 2520 reflections with $I>2 \sigma(I)$

$R_{\text {int }}=0.035$

$\theta_{\text {max }}=28.4^{\circ}, \theta_{\min }=2.7^{\circ}$

$h=-14 \rightarrow 14$

$k=-10 \rightarrow 9$

$l=-20 \rightarrow 20$ 


\section{Refinement}

Refinement on $F^{2}$

Least-squares matrix: full

$R\left[F^{2}>2 \sigma\left(F^{2}\right)\right]=0.026$

$w R\left(F^{2}\right)=0.058$

$S=1.03$

3065 reflections

145 parameters

0 restraints
Primary atom site location: structure-invariant direct methods

Hydrogen site location: inferred from neighbouring sites

$\mathrm{H}$-atom parameters constrained

$w=1 /\left[\sigma^{2}\left(F_{\mathrm{o}}^{2}\right)+(0.0289 P)^{2}+0.0779 P\right]$ where $P=\left(F_{\mathrm{o}}{ }^{2}+2 F_{\mathrm{c}}{ }^{2}\right) / 3$

$(\Delta / \sigma)_{\max }=0.001$

$\Delta \rho_{\max }=0.45 \mathrm{e} \AA^{-3}$

$\Delta \rho_{\min }=-0.40$ e $\AA^{-3}$

Special details

Geometry. All esds (except the esd in the dihedral angle between two 1.s. planes) are estimated using the full covariance matrix. The cell esds are taken into account individually in the estimation of esds in distances, angles and torsion angles; correlations between esds in cell parameters are only used when they are defined by crystal symmetry. An approximate (isotropic) treatment of cell esds is used for estimating esds involving l.s. planes.

Refinement. Owing to poor agreement, the (llll 111$)$ reflection was omitted from the final cycles of refinement.

Fractional atomic coordinates and isotropic or equivalent isotropic displacement parameters $\left(\hat{A}^{2}\right)$

\begin{tabular}{lllll}
\hline & $x$ & $y$ & $z$ & $U_{\text {iso }} * / U_{\text {eq }}$ \\
\hline Br1 & $0.50841(2)$ & $0.84764(3)$ & $0.90903(2)$ & $0.02370(8)$ \\
Br2 & $-0.25048(2)$ & $0.70383(3)$ & $0.09773(2)$ & $0.02253(8)$ \\
C1 & $0.4150(2)$ & $0.8055(3)$ & $0.78827(15)$ & $0.0159(5)$ \\
C2 & $0.3013(2)$ & $0.7135(3)$ & $0.77050(15)$ & $0.0161(4)$ \\
H2 & 0.269796 & 0.672242 & 0.817887 & $0.019^{*}$ \\
C3 & $0.2335(2)$ & $0.6817(3)$ & $0.68274(15)$ & $0.0177(5)$ \\
H3 & 0.155194 & 0.617644 & 0.670292 & $0.021^{*}$ \\
C4 & $0.2778(2)$ & $0.7417(3)$ & $0.61232(15)$ & $0.0167(5)$ \\
C5 & $0.3933(2)$ & $0.8356(3)$ & $0.63289(16)$ & $0.0187(5)$ \\
H5 & 0.425069 & 0.878319 & 0.585874 & $0.022^{*}$ \\
C6 & $0.4624(2)$ & $0.8674(3)$ & $0.72041(15)$ & $0.0173(5)$ \\
H6 & 0.541066 & 0.930801 & 0.733576 & $0.021^{*}$ \\
C7 & $0.2051(2)$ & $0.7034(4)$ & $0.51691(16)$ & $0.0255(6)$ \\
H7A & 0.218424 & 0.577129 & 0.503799 & $0.031^{*}$ \\
H7B & 0.241041 & 0.777365 & 0.477256 & $0.031^{*}$ \\
C8 & $0.0625(2)$ & $0.7386(3)$ & $0.49531(15)$ & $0.0212(5)$ \\
H8A & 0.025232 & 0.652822 & 0.529264 & $0.025^{*}$ \\
H8B & 0.049949 & 0.859257 & 0.516862 & $0.025^{*}$ \\
C9 & $-0.0116(2)$ & $0.7260(3)$ & $0.39829(14)$ & $0.0147(4)$ \\
C10 & $-0.1344(2)$ & $0.7992(3)$ & $0.36922(15)$ & $0.0167(5)$ \\
H10 & -0.170004 & 0.854105 & 0.411688 & $0.020^{*}$ \\
C11 & $-0.2056(2)$ & $0.7945(3)$ & $0.28122(15)$ & $0.0172(5)$ \\
H11 & -0.288380 & 0.846752 & 0.263034 & $0.021^{*}$ \\
C12 & $-0.1540(2)$ & $0.7119(3)$ & $0.21965(15)$ & $0.0161(4)$ \\
C13 & $-0.0336(2)$ & $0.6354(3)$ & $0.24522(15)$ & $0.0172(5)$ \\
H13 & 0.000460 & 0.578442 & 0.202509 & $0.021^{*}$ \\
C14 & $0.0369(2)$ & $0.6430(3)$ & $0.33433(15)$ & $0.0154(4)$ \\
H14 & 0.119669 & 0.590830 & 0.352166 & $0.018^{*}$ \\
& & & &
\end{tabular}


Atomic displacement parameters $\left(\AA^{2}\right)$

\begin{tabular}{lllllll}
\hline & $U^{11}$ & $U^{22}$ & $U^{33}$ & $U^{12}$ & $U^{13}$ & $U^{23}$ \\
\hline Br1 & $0.02109(13)$ & $0.02960(15)$ & $0.01712(13)$ & $-0.00317(9)$ & $-0.00014(9)$ & $-0.00484(9)$ \\
Br2 & $0.01971(13)$ & $0.03068(15)$ & $0.01471(12)$ & $-0.00164(9)$ & $0.00065(9)$ & $0.00265(9)$ \\
C1 & $0.0149(11)$ & $0.0157(12)$ & $0.0151(11)$ & $0.0040(8)$ & $0.0009(9)$ & $-0.0027(8)$ \\
C2 & $0.0160(11)$ & $0.0163(11)$ & $0.0175(11)$ & $0.0019(8)$ & $0.0073(9)$ & $0.0018(9)$ \\
C3 & $0.0136(11)$ & $0.0205(12)$ & $0.0185(12)$ & $-0.0004(8)$ & $0.0036(9)$ & $-0.0009(9)$ \\
C4 & $0.0146(11)$ & $0.0200(12)$ & $0.0152(11)$ & $0.0023(8)$ & $0.0036(9)$ & $-0.0006(9)$ \\
C5 & $0.0146(11)$ & $0.0216(12)$ & $0.0214(12)$ & $0.0015(9)$ & $0.0076(9)$ & $0.0038(9)$ \\
C6 & $0.0106(10)$ & $0.0172(12)$ & $0.0243(12)$ & $-0.0004(8)$ & $0.0053(9)$ & $-0.0012(9)$ \\
C7 & $0.0160(12)$ & $0.0436(16)$ & $0.0171(12)$ & $0.0027(10)$ & $0.0050(10)$ & $-0.0026(11)$ \\
C8 & $0.0166(12)$ & $0.0281(13)$ & $0.0172(12)$ & $0.0018(10)$ & $0.0021(9)$ & $-0.0023(10)$ \\
C9 & $0.0169(11)$ & $0.0132(11)$ & $0.0146(11)$ & $-0.0018(8)$ & $0.0054(9)$ & $0.0007(8)$ \\
C10 & $0.0173(11)$ & $0.0152(12)$ & $0.0195(12)$ & $-0.0002(8)$ & $0.0082(9)$ & $0.0003(9)$ \\
C11 & $0.0129(10)$ & $0.0172(12)$ & $0.0211(12)$ & $0.0006(8)$ & $0.0039(9)$ & $0.0026(9)$ \\
C12 & $0.0160(11)$ & $0.0175(12)$ & $0.0133(10)$ & $-0.0038(8)$ & $0.0015(9)$ & $0.0025(9)$ \\
C13 & $0.0189(11)$ & $0.0165(12)$ & $0.0174(11)$ & $-0.0011(9)$ & $0.0070(9)$ & $-0.0003(9)$ \\
C14 & $0.0129(11)$ & $0.0160(11)$ & $0.0176(11)$ & $-0.0012(8)$ & $0.0048(9)$ & $0.0015(9)$ \\
& & & & & & \\
\hline
\end{tabular}

Geometric parameters $\left(\AA,{ }^{\circ}\right)$

\begin{tabular}{|c|c|c|c|}
\hline $\mathrm{Br} 1-\mathrm{C} 1$ & $1.902(2)$ & C7-H7B & 0.9900 \\
\hline $\mathrm{Br} 2-\mathrm{C} 12$ & $1.901(2)$ & $\mathrm{C} 8-\mathrm{C} 9$ & $1.507(3)$ \\
\hline $\mathrm{C} 1-\mathrm{C} 2$ & $1.376(3)$ & $\mathrm{C} 8-\mathrm{H} 8 \mathrm{~A}$ & 0.9900 \\
\hline $\mathrm{C} 1-\mathrm{C} 6$ & $1.382(3)$ & $\mathrm{C} 8-\mathrm{H} 8 \mathrm{~B}$ & 0.9900 \\
\hline $\mathrm{C} 2-\mathrm{C} 3$ & $1.384(3)$ & $\mathrm{C} 9-\mathrm{C} 10$ & $1.399(3)$ \\
\hline $\mathrm{C} 2-\mathrm{H} 2$ & 0.9500 & $\mathrm{C} 9-\mathrm{C} 14$ & $1.399(3)$ \\
\hline $\mathrm{C} 3-\mathrm{C} 4$ & $1.393(3)$ & $\mathrm{C} 10-\mathrm{C} 11$ & $1.377(3)$ \\
\hline $\mathrm{C} 3-\mathrm{H} 3$ & 0.9500 & $\mathrm{C} 10-\mathrm{H} 10$ & 0.9500 \\
\hline $\mathrm{C} 4-\mathrm{C} 5$ & $1.398(3)$ & $\mathrm{C} 11-\mathrm{C} 12$ & $1.388(3)$ \\
\hline $\mathrm{C} 4-\mathrm{C} 7$ & $1.507(3)$ & C11-H11 & 0.9500 \\
\hline $\mathrm{C} 5-\mathrm{C} 6$ & $1.385(3)$ & $\mathrm{C} 12-\mathrm{C} 13$ & $1.384(3)$ \\
\hline $\mathrm{C} 5-\mathrm{H} 5$ & 0.9500 & $\mathrm{C} 13-\mathrm{C} 14$ & $1.390(3)$ \\
\hline $\mathrm{C} 6-\mathrm{H} 6$ & 0.9500 & $\mathrm{C} 13-\mathrm{H} 13$ & 0.9500 \\
\hline $\mathrm{C} 7-\mathrm{C} 8$ & $1.516(3)$ & $\mathrm{C} 14-\mathrm{H} 14$ & 0.9500 \\
\hline $\mathrm{C} 7-\mathrm{H} 7 \mathrm{~A}$ & 0.9900 & & \\
\hline $\mathrm{C} 2-\mathrm{C} 1-\mathrm{C} 6$ & $121.4(2)$ & $\mathrm{C} 9-\mathrm{C} 8-\mathrm{C} 7$ & $116.1(2)$ \\
\hline $\mathrm{C} 2-\mathrm{C} 1-\mathrm{Br} 1$ & 119.02 (17) & $\mathrm{C} 9-\mathrm{C} 8-\mathrm{H} 8 \mathrm{~A}$ & 108.3 \\
\hline $\mathrm{C} 6-\mathrm{C} 1-\mathrm{Br} 1$ & 119.57 (17) & $\mathrm{C} 7-\mathrm{C} 8-\mathrm{H} 8 \mathrm{~A}$ & 108.3 \\
\hline $\mathrm{C} 1-\mathrm{C} 2-\mathrm{C} 3$ & $119.2(2)$ & $\mathrm{C} 9-\mathrm{C} 8-\mathrm{H} 8 \mathrm{~B}$ & 108.3 \\
\hline $\mathrm{C} 1-\mathrm{C} 2-\mathrm{H} 2$ & 120.4 & $\mathrm{C} 7-\mathrm{C} 8-\mathrm{H} 8 \mathrm{~B}$ & 108.3 \\
\hline $\mathrm{C} 3-\mathrm{C} 2-\mathrm{H} 2$ & 120.4 & $\mathrm{H} 8 \mathrm{~A}-\mathrm{C} 8-\mathrm{H} 8 \mathrm{~B}$ & 107.4 \\
\hline $\mathrm{C} 2-\mathrm{C} 3-\mathrm{C} 4$ & $121.3(2)$ & $\mathrm{C} 10-\mathrm{C} 9-\mathrm{C} 14$ & $117.4(2)$ \\
\hline $\mathrm{C} 2-\mathrm{C} 3-\mathrm{H} 3$ & 119.4 & $\mathrm{C} 10-\mathrm{C} 9-\mathrm{C} 8$ & 119.73 (19) \\
\hline $\mathrm{C} 4-\mathrm{C} 3-\mathrm{H} 3$ & 119.4 & $\mathrm{C} 14-\mathrm{C} 9-\mathrm{C} 8$ & $122.9(2)$ \\
\hline $\mathrm{C} 3-\mathrm{C} 4-\mathrm{C} 5$ & $117.9(2)$ & $\mathrm{C} 11-\mathrm{C} 10-\mathrm{C} 9$ & $122.3(2)$ \\
\hline
\end{tabular}




$\begin{array}{llll}\mathrm{C} 3-\mathrm{C} 4-\mathrm{C} 7 & 121.1(2) & \mathrm{C} 11-\mathrm{C} 10-\mathrm{H} 10 & 118.8 \\ \mathrm{C} 5-\mathrm{C} 4-\mathrm{C} 7 & 120.9(2) & \mathrm{C} 9-\mathrm{C} 10-\mathrm{H} 10 & 118.8 \\ \mathrm{C} 6-\mathrm{C} 5-\mathrm{C} 4 & 121.3(2) & \mathrm{C} 10-\mathrm{C} 11-\mathrm{C} 12 & 118.6(2) \\ \mathrm{C} 6-\mathrm{C} 5-\mathrm{H} 5 & 119.3 & \mathrm{C} 10-\mathrm{C} 11-\mathrm{H} 11 & 120.7 \\ \mathrm{C} 4-\mathrm{C} 5-\mathrm{H} 5 & 119.3 & \mathrm{C} 12-\mathrm{C} 11-\mathrm{H} 11 & 120.7 \\ \mathrm{C} 1-\mathrm{C} 6-\mathrm{C} 5 & 118.8(2) & \mathrm{C} 13-\mathrm{C} 12-\mathrm{C} 11 & 121.3(2) \\ \mathrm{C} 1-\mathrm{C} 6-\mathrm{H} 6 & 120.6 & \mathrm{C} 13-\mathrm{C} 12-\mathrm{Br} 2 & 119.32(17) \\ \mathrm{C} 5-\mathrm{C} 6-\mathrm{H} 6 & 120.6 & \mathrm{C} 11-\mathrm{C} 12-\mathrm{B} 2 & 119.41(17) \\ \mathrm{C} 4-\mathrm{C} 7-\mathrm{C} 8 & 114.2(2) & \mathrm{C} 12-\mathrm{C} 13-\mathrm{C} 14 & 12.0(2) \\ \mathrm{C} 4-\mathrm{C} 7-\mathrm{H} 7 \mathrm{~A} & 108.7 & \mathrm{C} 12-\mathrm{C} 13-\mathrm{H} 13 & 120.5 \\ \mathrm{C} 8-\mathrm{C} 7-\mathrm{H} 7 \mathrm{~A} & 108.7 & \mathrm{C} 14-\mathrm{C} 13-\mathrm{H} 13 & 121.4(2) \\ \mathrm{C} 4-\mathrm{C} 7-\mathrm{H} 7 \mathrm{~B} & 108.7 & \mathrm{C} 13-\mathrm{C} 14-\mathrm{C} 9 & 119.3 \\ \mathrm{C} 8-\mathrm{C} 7-\mathrm{H} 7 \mathrm{~B} & 108.7 & \mathrm{C} 13-\mathrm{C} 14-\mathrm{H} 14 & 119.3 \\ \mathrm{H} 7 \mathrm{~A}-\mathrm{C} 7-\mathrm{H} 7 \mathrm{~B} & 107.6 & \mathrm{C} 9-\mathrm{C} 14-\mathrm{H} 14 & -163.7(2) \\ & & & 16.4(3) \\ \mathrm{C} 6-\mathrm{C} 1-\mathrm{C} 2-\mathrm{C} 3 & 0.3(3) & \mathrm{C} 7-\mathrm{C} 8-\mathrm{C} 9-\mathrm{C} 10 & -1.3(3) \\ \mathrm{Br} 1-\mathrm{C} 1-\mathrm{C} 2-\mathrm{C} 3 & -179.64(16) & \mathrm{C} 7-\mathrm{C} 8-\mathrm{C} 9-\mathrm{C} 14 & 178.8(2) \\ \mathrm{C} 1-\mathrm{C} 2-\mathrm{C} 3-\mathrm{C} 4 & -0.3(3) & \mathrm{C} 14-\mathrm{C} 9-\mathrm{C} 10-\mathrm{C} 11 & 0.9(3) \\ \mathrm{C} 2-\mathrm{C} 3-\mathrm{C} 4-\mathrm{C} 5 & 0.0(3) & \mathrm{C} 8-\mathrm{C} 9-\mathrm{C} 10-\mathrm{C} 11 & 0.0(3) \\ \mathrm{C} 2-\mathrm{C} 3-\mathrm{C} 4-\mathrm{C} 7 & 178.7(2) & \mathrm{C} 9-\mathrm{C} 10-\mathrm{C} 11-\mathrm{C} 12 & -179.99(16) \\ \mathrm{C} 3-\mathrm{C} 4-\mathrm{C} 5-\mathrm{C} 6 & 0.4(3) & \mathrm{C} 10-\mathrm{C} 11-\mathrm{C} 12-\mathrm{C} 13 & -0.5(3) \\ \mathrm{C} 7-\mathrm{C} 4-\mathrm{C} 5-\mathrm{C} 6 & -178.3(2) & \mathrm{C} 10-\mathrm{C} 11-\mathrm{C} 12-\mathrm{Br} 2 & 179.49(16) \\ \mathrm{C} 2-\mathrm{C} 1-\mathrm{C} 6-\mathrm{C} 5 & 0.0(3) & \mathrm{C} 11-\mathrm{C} 12-\mathrm{C} 13-\mathrm{C} 14 & 0.1(3) \\ \mathrm{Br} 1-\mathrm{C} 1-\mathrm{C} 6-\mathrm{C} 5 & 179.96(16) & \mathrm{Br} 2-\mathrm{C} 12-\mathrm{C} 13-\mathrm{C} 14 & -179.4(2) \\ \mathrm{C} 4-\mathrm{C} 5-\mathrm{C} 6-\mathrm{C} 1 & -0.4(3) & \mathrm{C} 12-\mathrm{C} 13-\mathrm{C} 14-\mathrm{C} 9 & \\ \mathrm{C} 3-\mathrm{C} 4-\mathrm{C} 7-\mathrm{C} 8 & 46.6(3) & \mathrm{C} 10-\mathrm{C} 9-\mathrm{C} 14-\mathrm{C} 13 & \\ \mathrm{C} 5-\mathrm{C} 4-\mathrm{C} 7-\mathrm{C} 8 & -134.8(2) & \mathrm{C} 8-\mathrm{C} 9-\mathrm{C} 14-\mathrm{C} 13 & \\ \mathrm{C} 4-\mathrm{C} 7-\mathrm{C} 8-\mathrm{C} 9 & 172.1(2) & & \\ & & & \end{array}$

Hydrogen-bond geometry $\left(A,{ }^{\circ}\right)$

$C g 1$ and $C g 2$ are the centroids of the $(\mathrm{C} 1-\mathrm{C} 6)$ and (C9-C14) rings, respectively.

\begin{tabular}{lllll}
\hline$D-\mathrm{H} \cdots A$ & $D-\mathrm{H}$ & $\mathrm{H} \cdots A$ & $D \cdots A$ & $D-\mathrm{H} \cdots A$ \\
\hline $\mathrm{C} 3-\mathrm{H} 3 \cdots C g 2^{\mathrm{i}}$ & 0.95 & 2.69 & $3.442(2)$ & 136 \\
$\mathrm{C} 6-\mathrm{H} 6 \cdots C g 1^{\mathrm{ii}}$ & 0.95 & 2.91 & $3.704(2)$ & 141 \\
$\mathrm{C} 13-\mathrm{H} 13 \cdots C g 2^{\mathrm{iii}}$ & 0.95 & 2.87 & $3.569(2)$ & 131 \\
\hline
\end{tabular}

Symmetry codes: (i) $-x,-y+1,-z+1$; (ii) $-x+1, y+1 / 2,-z+3 / 2$; (iii) $-x, y-1 / 2,-z+1 / 2$. 